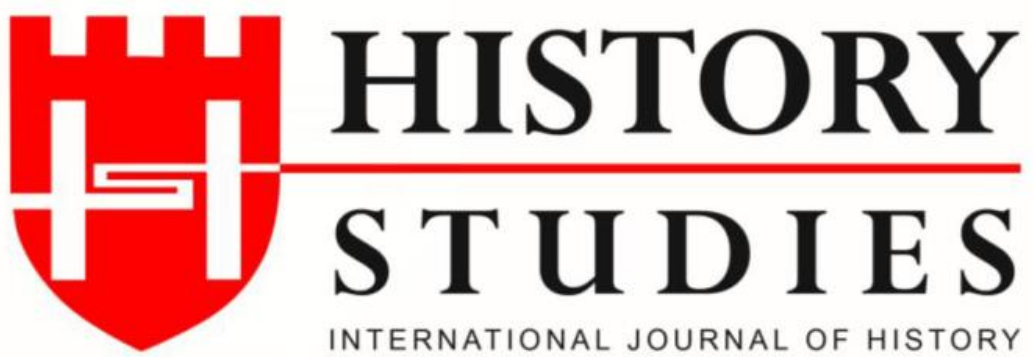

ISSN: 13094173 (Online) 1309 - 4688 (Print)

Volume 12 Issue 2, A Tribute to Assoc. Prof. Dr. İlknur Mangır Karagöz, April 2020 DOI Number: 10.9737/hist.2020.847

Araştırma Makalesi

Makalenin Geliş Tarihi: 24.12.2019 Kabul Tarihi: 09.03.2020

Atıf Künyesi: Akın Temür - Davut Yiğitpaşa, “Neoklaudiopolis Antik Kenti ve Territoryumu 2018

Yüzey Araştırması ve Envanter Çalışmaları", History Studies, Doç. Dr. İlknur Mangır Karagöz

Armağan1, 12/2, Nisan 2020, s. 619-654.

\title{
Neoklaudiopolis Antik Kenti ve Territoryumu 2018 Yüzey Araştırması ve Envanter Çalışmaları
}

\author{
Neoklaudiopolis Ancient City and Territory 2018 Surveys and Inventory Studies
}

\author{
Dr. Akın Temür - Doç. Dr. Davut Yiğitpaşa \\ ORCID No: 0000-0001-9777-5256 / 0000-0001-8821-5628 \\ Ondokuz Mayıs Üniversitesi
}

Volume 12

Issue 2

A Tribute to

Assoc. Prof.

Dr. İlknur

Mangir

Karagöz,

April

2020

\begin{abstract}
Öz: Vezirköprü İlçesinin tarihini araştırmak, İlçedeki arkeolojik kültür varlıklarını tespit etmek ve Neoklaudiopolis Antik Kenti'nin lokalizasyonunu ve çevresiyle olan ilişkilerini ortaya koyabilmek amacıyla 5 yıllık bir yüzey araştırması planlanmıştır. Bu planlama kapsamında 2018 yılında Samsun İli Vezirköprü İlçesinde ilk çalışmalara başlanmıștır. 2018 yılı yüzey araştırması, Vezirköprü ilçesine bağl1 27 köyde yürütülmüştür. Bu sezon yürütülen çalışmaların odak noktasını özellikle Roma kalıntılarının yoğunlaştığı İstavloz (İstavroz) Çayı çevresinde bulunan köyler oluşturmuştur. $\mathrm{Bu}$ çalışmalar sırasında, tescilli olanlarla birlikte, 3 kale ve 15 yamaç yerleşimi, 2 höyük, 3 adet köprü, 4 adet mimari yapı kalıntısı, 15 tümülüs, 8 taş sandık mezar, 6 kaya oygu mezar, 10 lahit teknesi ve kapağı, 7 adet mezar steli, 1 kaya mezarı, 4 adet mimari yapı kalıntısı, çok sayıda işlik, sütun, sütun başlığı ve altlığı, mimari yapı elamanı, mezar steli, mil taşı ayrıntılı bir şekilde araştırılarak koordinatları belirlenerek fotoğraflanıp kayıt altına alınmıştır.
\end{abstract}

Anahtar Sözcükler: Karadeniz, Samsun, Vezirköprü, Neoklaudiopolis, Roma Yerleşimleri

\begin{abstract}
A 5-year survey was planned in order to reveal the localization of Neoklaudiopolis and its relations with its surroundings and to investigate the history of Vezirköprü district, to identify the archaeological cultural assets in the district. Within the scope of this planning, in 2018, the first works were started in Vezirköprü District of Samsun Province. The survey in 2018 was conducted in 27 villages of the Vezirköprü district. The focus of this season's work was on villages in the vicinity of Istavloz (Istavroz) Stream, especially where the Roman remains were concentrated. During these studies, were investigated in detail and their coordinates were determined and photographed and recorded together with the registered ones, 3 fortresses and 15 slope settlements, 2 mounds, 3 bridges, 4 architectural remains, 15 tumuli, 8 stone crate tombs, 6 rock grave tombs, 10 sarcophagus vessels and hatches, 7 tombstones, 1 rock tomb, 4 architectural remains, a large number of workshops, column, column header and base, architectural building element, grave steles, milestones detailed by determining the coordinates were investigated under and recorded.
\end{abstract}

Keywords: Black Sea, Samsun, Vezirköprü, Neoklaudiopolis, Roman Settlements

Giriş

Vezirköprü, Samsun İline bağlı bir ilçe olup, Samsun'un $110 \mathrm{~km}$. batısında bulunmaktadır. İlçe, kuzeyde Alaçam ve Sinop'un Durağan, kuzeydoğuda Bafra, doğuda Havza, güneybatıda 
Çorum'un Osmancık ve batıda Sinop'un Saraydüzü İlçeleriyle çevrilidir. Bölge engebeli topografyası ve ovalarıyla oldukça farklı bir yaşam alanı sunmaktadır. Vezirköprü Ovası 350 m. ve daha aşağı yükseltilerde yer almaktadır. İncesu, İnkaya, Örencik, Avdan, Adatepe, Yağınözü Mahallelerini ve arazilerini içine alan bir sahayı kapsamaktadır. Ovanın meyli güneyden kuzeye doğru gelişmiştir. Ovalık saha Çayözü Deresi, Çorakdere ve kolları tarafından hafifçe yarılmıştır. Vezirköprü'de geçici ve sürekli olmak üzere irili ufaklı çok sayıda akarsu bulunmaktadır. Bu akarsuların en önemlileri başta İstavloz Çayı olmak üzere, Esenli Çayı, Uluçay, Kürtler Çayı ve Gölçayı'dır. Vezirköprü ve yakın çevresinin suları Kızılırmak'ın iki büyük kolu tarafından drene edilmektedir. Bunlar yaklaşık olarak kuzeye doğru akan Akçay ile kuzeydoğu yönlü Gölçay-Kürtler Çayı'dır. Vezirköprü'nün bu Jeomorfolojisi, ovası, akarsu vadileri ve deltalarıyla farklı bir eko-sistemi ortaya çıarmaktadır. Kültürlerin biçimlenmesinde coğrafya ve ekolojik koşullar önemli bir yer tuttuğu bilinen bir gerçektir. Vezirköprü coğrafyası da yerleşime uygun alanları bulunması ve ikliminin sürekli yerleşmeye uygun bir ortam oluşturmasından dolayı binlerce yıl boyunca farklı uygarlıkların sürekli olarak iskan ettiği önemli bir bölge konumuna sahip olmuştur.

Vezirköprü İlçesinde (Harita 1) en kapsamlı çalışmalar Oymaağaç Mahallesi sınırları içinde bulunan Oymaağaç Höyügü̈'nde yürütülmüştür. Vezirköprü'nün 7 km. kuzeyinde, Çal Sırtı ile Oymaağaç Vadisi arasında yer alan höyük, ilk olarak 1970 yılında Dengate tarafından tespit edilmiştir. ${ }^{1}$ Sonrasında Alkım ve ekibi tarafından Samsun ve ilçelerinde 1971-1977 yılları arasında bir yüzey araştırması gerçekleştirilmiştir. ${ }^{2}$ Yüzey araştırmaları sonrasında 2005 yılında Czichon tarafından başlatılan kazılar günümüzde de halen devam etmektedir. ${ }^{3}$ Vezirköprü'de yürütülen bu çalışmaların yanında antik kaynaklarda adı geçen Neoklaudiopolis ${ }^{4}$ antik kentine ait yazitlar ve sikkeler ilgili olarak French, Kahl ve Olshausen tarafindan 80'li ve 90'l1 yıllarda çalışmalar yürütülmüştür. ${ }^{5}$ Sonraki yıllarda Neoklaudiopolis antik kenti ve Roma yollarını saptamak amacıyla Tønnes Bekker-Nielsen başkanlığındaki Danimarkalı bir ekip tarafından, 2010 ve 2013 yıllarında yüzey araştırmaları gerçekleştirilmiştir. ${ }^{6}$ Görüldüğü üzere mevcut

\footnotetext{
${ }^{1}$ J. Andrew Dengate, "A Site Survey along the South Shore of Black Sea”, The Proceedings of the Xth International Congress of Classical Archaeology, Ankara-İzmir 23-30/IX/1973, 1, 1978, s. 245-258.

${ }^{2}$ U. Bahadır Alkım, "İslâhiye ve Samsun Bölgesinde 1971 Çalışmaları", Belleten XXXVI-143, 1972, s. 422-426; "İslâhiye ve Samsun Bölgesinde 1972 Çalışmaları", Belleten XXXVII-147, 1973, s. 435-438; "Tilmen Höyük ve Samsun Bölgesi Çalışmaları 1971", Türk Arkeoloji Dergisi, 20-2, 1974a, s. 5-16; "Samsun Bölgesinde 1973 Çalışmaları", Belleten XXXVIII-151, 1974b, s. 553-556, "Tilmen Höyük ve Samsun Bölgesi Çalışmaları 1972", Türk Arkeoloji Dergisi 21-2, 1975a, s. 23-28; "Samsun Bölgesi Çalışmalar1 1973”, Türk Arkeoloji Dergisi 22-2, 1975b, s. 5-12; "Samsun Bölgesi Araştırmaları ve İkinci Dönem İkiztepe Kazısı", Belleten XL-160, 1976, s. 717719; 1977 Dönemi İkiztepe Kazısı ve Samsun Bölgesi Araştırmaları”, Belleten XLII-167, 1978, s. 542-547; Zeynep Kızıltan "Samsun Bölgesi Yüzey Araştırmaları", Belleten LVI-215, 1992, s. 213-241.

${ }^{3}$ Rainer M. Czichon, Oymaagac-Vezirköprü-Survey Report 2005, in: M.H. Gates/B. Yıldırım, Archaeology in Turkey", American Journal of Archaeology 111,2, 2007, s. 300; Oymaağaç- Vezirköprü Yüzey Araştırması 2006”, 25. Araştırma Sonuçları Toplantısı 1, 2008, s. 187-196; Rainer M. Czichon- Jörg Klinger, "Karadeniz'deki Hititler: Nerik-Zalpa", Aktüel Arkeoloji Dergisi, Kasım 8, 2010, s. 58-65; Czichon, Rainer M., - Jörg Klinger - Peter Breuer Jacop Eerbeek - Sherry Fox - Elena Marinova-Wolff - Henning Marquardt - Harald von der Osten-Woldenburg Silvio Reichmuth - Simone Riehl - Theodor Johannsen, "Archäologische Forschungen am Oymaağaç Höyük/Nerik (?) in den Jahren 2007-2010", Mitteilungen der Deutschen Orient-Gesellschaft 143, 2011, s. 169-250.

${ }^{4} \mathrm{Bu}$ konuda ayrıntılı bilgi için bkz. Tønnes Bekker-Nielsen, "Neoklaudiopolis'in Araştırma Tarihi Üzerine Notlar (Vezirköprü, Samsun İli)", Höyük 6, 2013b, s. 39-59.

${ }^{5}$ David French, Roman Roads and Milestones of Asia Minor, Fasc. 2.1: An Interim Catalogue of Milestones (British Institute of Archaeology at Ankara Monograph, 9; British Archaeological reports, International Series, 392/I), Oxford 1988; Kahl, Gerhard- Eckart Olshausen, "Bericht über die Epigraphische und Numismatische Landesaufname im Samsun İli 1990", Araştırma Sonuçları Toplantısı, 1991, s. 612-613.

${ }^{6}$ Tønnes Bekker-Nielsen, "New milestones from Neoklaudiopolis", Epigraphica Anatolica 43, 2010, s. 87-91; Tønnes Bekker-Nielsen - Christian Högel 2012, "Three Epitaphs from the Vezirköprü Region”, Epigraphica Anatolica 45, 2012, s. 153-160; Tønnes Bekker-Nielsen, Neapolis-Neoklaudiopolis: A Roman City in Northern
} 
çalışmalar daha çok yazıtlar ve mil taşları üzerinde yoğunlaşmaktadır. Bütün bu çalışmalara karşın Vezirköprü'yü bir bütün olarak ele alıp, tüm yönüyle değerlendiren bir envanter çalışması maalesef yapılabilmiş değildir. Ayrıca bölgede yapılan araştırmalarda özellikle kaçak kazı yapılan alanların birçoğunun, tescillenmesi gereken alanlar üzerinde olduğu gözlemlenmiştir. Bunun önüne geçilebilmesi ve antik kaynaklarda adı geçen, ancak şu ana kadar yeri tam olarak belirlenememiş olan Neoklaudiopolis antik kentinin sınırlarının belirlenebilmesi için, çok kapsamlı ve her yönüyle değerlendirmeye tabi tutulan, uzun soluklu bir araştırmaya ihtiyaç duyulmuştur. Bu amaçla 2018 yılında Vezirköprü İlçe merkezi ve köylerini kapsayacak bir şekilde "Neoklaudiopolis Antik Kenti ve Territoryumu" adıyla yeni bir yüzey araştırması projesi başlatılmıştır. ${ }^{7}$ İlk sezon çalışmalarının odak noktasını Roma kalıntılarının yoğun olarak görüldügü İstavloz (İstavroz) Çayı çevresinde bulunan köyler oluşturmaktadır (Harita 2). İlçe merkezine bağlı 27 köyde gerçekleştirilen bu çalışmalar sırasında tespit edilen buluntuların koordinatları GPS ile haritaya işlenmiş ve gerekli görülen alanlarda tarihlemek amacıyla nitelikli seramiklerden örnekler toplanmıştır.

Arazi çalışmaları sırasında elde edilen veriler savunma yapıları, su yapıları, yerleşimler ve mezar yapıları olmak üzere 4 başlık altında değerlendirilmiştir.

\section{Savunma Yapıları}

Bölgede yapılan incelemelerde; Vezirköprü coğrafyasının büyük ölçüde kayalık bir yapıya sahip olmasından ötürü, savunmanın da büyük ölçüde bu tip alanlarda yoğunlaştığ görülmektedir. $\mathrm{Bu}$ kapsamda çalışmalar sırasında büyük tahkimatlı sur duvarlarından çok, kayalık alanlar üzerinde yapılmış ve yer yer sur duvarlarıyla destekleniş kule tipi bir savunma sisteminin oluşturulduğu izlenmektedir.

\subsection{Kaleler}

İlk sezon çalışmalarında üç adet kale tespit edilmiştir. Bunlardan ilki Çalköy'den Yörükçal yönüne giden yolun solunda, Gavurevi Mevkii olarak adlandırılan yerde bulunan yamaç yerleşiminin üst tarafında, araziye hakim bir noktada bulunmaktadır (Res. 1). Kale yaklaşık 200 m. uzunluğunda ve dikdörtgen bir plana sahiptir. Hilal şeklinde sur duvarı çok küçük, işlenmemiş kaba taşlardan yapılmıştır. Sur duvarının doğu uç bölümünde kaçak kazı çukurları tespit edilmiştir. Kalenin kuzeyi sarp kayalıklardan oluştuğu için o bölümde sura ihtiyaç duyulmamıştır. Biraz daha az eğimli olan güney-güneybatısını savunmak amacıyla yapılmış surun kalınlığı, küçük taşların üzerine ve yanlara doğru yıkılmasından dolayı tespit edilememiştir. Sur inşası sırasında küçük boyutlu işlenmemiş taşların dolgu amaciyla kullanılmış olduğu görülmesine karşın, daha büyük boyutlu olan surun dış kısımlarında bulunması gereken taşlar tespit edilememiştir. Muhtemelen yıkıntıların altında kalmış olmalıdır. Yıkıntıların bir tepe oluşturması kaba olmakla birlikte güçlü bir surun varlığını işaret etmektedir. Kalenin tam güneyinde bulunan bölümde, surun iç bölümündeki düzlük alanda taş kalıntılarından ve define çukurlarından, iç bölümde sura bitişik bir yapılar grubu bulunduğu anlaşılmaktadır.

İkinci kale Vezirköprü merkezinin $13 \mathrm{~km}$. güneydoğusundaki Tekkekıran Mahallesi'nin 1,5 km. güneydoğusunda, Kale Mevkii’nde bulunmaktadır (Res. 2). Doğu-batı yönünde uzanan

Anatolia, (Ed. Ünsal Yalçın), Anatolian Metal VI, 203-213, Bochum 2013a, s. 203-213; Tønnes Bekker-Nielsen, Rainer M. Czichon-Christian Högel-Bünyamin Kıvrak- Jesper M. Madsen-Vera Sauer-Soren L. Sorensen-Kristina Winther-Jacobsen, Neoklaudioplis Antik Kenti (Vezirköprü-Samsun) Tarihsel ve Arkeolojik Rehber (Çev. Özge Acar), İstanbul 2015a, s. 1-96.

$7 \mathrm{Bu}$ çalışma, Ondokuz Mayıs Üniversitesi, Bilimsel Araştırma Geliştirme Destekleme Programı (PYO.FEN.1901.18.006) tarafından desteklenmiştir. 
kale, İstavloz Çayı'nın batısında yüksek kayalık bir alan üzerinde, vadiye hakim bir noktada yer almaktadır. Kale üzerinde yapılan incelemeler sırasında çok sayıda horasan harçlı duvar kalıntısı tespit edilmiştir. Ayrıca kayalık alanda yer yer sur duvarları için setler oluşturulduğu görülmektedir. Kalenin doğu tarafını İstavroz Çayı'nın aktığı uçurum, batı tarafını ise, üzerinde yamaç yerleşimi bulunan bir tarım arazisi çevirmektedir. Çayın karşı tarafı Havza sınırlarına girmektedir.

Üçüncü kale Vezirköprü merkezinin $15 \mathrm{~km}$. kuzeydoğusunda bulunan Özyörük Mahallesi'nde, mahallenin $500 \mathrm{~m}$. güneybatısında, $35 \mathrm{~m}$. yükseklikte, kayalık dik bir yamaç üzerinde bulunmaktadır (Res. 3). Sarp kayalıklar üzerinde kurulan yerleşimin üç tarafını dik bir uçurum çevirmektedir. Kaleye çıkış ancak kayalığın doğuya bakan tarafında bulunan ve kaya mezarına çıkışı sağlayan, kayaya oyulmuş düzensiz basamaklar aracılığıyla mümkündür. Kalenin üzerinde $15 \times 15$ m.'lik düz bir platform bulunmaktadır. Yapılan araştırmalar sırasında kalede üç adet sarnıç tespit edilmiştir.

\subsection{Kuleler}

Çalışmalar sırasında iki adet kule yapısı tespit edilmiştir. Bu kule yapılarına baktığımızda; kesme taştan yapılmış belirli bir mimari form gösteren yapılardan çok, kayalık alanların düzleştirilmesi ve yer yer moloz taş örgülü duvarlarla desteklenmesi şeklinde yapıldığına tanık oluruz. İlk örneğimiz Çekalan Mahallesi’nin 300 m. güneyinde, Acısu Deresi'nin hemen yanında, Kocakarıpınarı Mevkii'ndeki tescilli yamaç yerleşiminin araziye hakim bir noktası üzerinde bulunmaktadır (Res. 4). Bir sur sistemine bağlı olmaksızın, kayalık bir alanın doğal yapısı kullanılarak oluşturulan kule yapısı üzerine; yer yer kayaya oyulmuş 12 adedi yüzeysel, 23 adedi düzenli işlenmiş basamakları olan bir merdivenle çıkılmaktadır. İlk bakışta kayalık alanın bir açık hava tapınma alanı olabileceği akla gelse de, kayalık alan üzerinde herhangi bir niş veya sunu çukuruna rastlanmaması, ayrıca kayalık alanın bir yamaç yerleşimi içinde, araziye hakim bir noktada konumlanmış olması onun daha çok kule işleviyle kullanılmış olabileceği kanaatini güçlendirmektedir. Kulenin çevresindeki yamaç yerleşimi üzerinde yapılan incelemelerde, dağınık şekilde Tunç, Demir, Hellenistik, Roma ve Bizans dönemlerine ait çok sayıda seramik buluntusuna rastlanmıştır. $\mathrm{Bu}$ da söz konusu alanın, çok erken dönemlerden itibaren savunma amaçlı olarak kullanılmış olabileceğini göstermesi açısından oldukça önemlidir.

İkinci kule yapısı Vezirköprü merkezinin 19 km. kuzeydoğusunda, Kaplancık Mahallesi’nin Gavuryolu Mevkii'nde bulunmaktadır (Res. 5). Kaplancık Kanyonu'nun girişinde bulunan yapı, bir çıkıntı şeklinde uzanan alçak bir kayalık alan üzerinde bulunmakta olup, üzerinde horasan harçlı duvar kalıntıları görülmektedir. Yapının Kaplancık yerleşiminin girişinde bulunmasından yerleşim için bir gözetleme kulesi ya da savunma amaçlı yapılan bir yapı olduğu kanaatine ulaşılmıştır. Ayrıca kayalık alan üzerinde zirveye doğru çıkan, bu yüzden Gavur Yolu olarak adlandırılan, seyrek ve yüzeysel olarak yapılmış kaya basamaklarının tespit edilmiş olması da bu görüşü destekler niteliktedir.

\section{Su Yapıları}

Köprüler kenti olan Vezirköprü tarih boyunca birçok kültüre ev sahipliği yapmış olup önemli bir geçiş güzergahı üzerinde yer almaktadır. Bu kapsamda da gerek günümüzde ve gerekse antik dönemlerde yapılmış pek çok köprüye ev sahipliği yapmaktadır. Yapılan çalışmalar sarasında ise Istavloz Çayı üzerinde olmak üzere üç adet antik köprü ve kalıntılarına rastlanmıştır. 


\subsection{Köprüler}

İlk köprü kalıntısı Vezirköprü merkezinin 7 km. doğusunda bulunan Yürükçal Mahallesi'nin hemen altından geçen Istavloz Çayı üzerinde bulunmaktadır (Res. 6). Söz konusu alanda Roma dönemine ait olduğu düşünülen köprü ayakları tespit edilmiştir. ${ }^{8}$ Kuzey-güney doğrultusunda 4 ayağı günümüze ulaşabilmiş olan köprünün (köylüler eskiden 7 ayağının görüldüğünü ifade etmektedir) ayaklar arasındaki mesafe yaklaşık 7 m.'dir. Köprünün dere yatağına olan taraftaki ayakları moloz taş örgülü, harçlı zemin içine gömülmüş mermer bloklardan oluşmakta olup, 8 x8 m. ölçülerindeki bir zemin üzerine oturmaktadır. Bu zemin blokları 20-40 cm. arasında değişen kalınlıkta ve farklı ölçülerdedir. Mermer zemin üzerine $3.60 \times 2.75 \mathrm{~m}$. ölçülerindeki ayak yerleştirilmiştir. $75 \mathrm{~cm}$. yüksekliğindeki bir sırası korunmuş ayaklar, $40 \mathrm{~cm}$. genişliğindeki mermer kaplama içinde moloz taş örgülü olarak yapılmıştır. Güneyden 2. ayak üzerinde korunmuş 1.70 m.'lik harç izlenebilmektedir. Ayakların Yürükçal Mahallesi tarafındaki izlerine rastlanmamıştır. Olasılıkla dereye paralel olarak açılan köy yolunun yapımı sırasında tahrip edilmiş olmuş olabileceği düşünülmektedir.

İkinci köprü; Vezirköprü merkezinin $13 \mathrm{~km}$. güneydoğusundaki Tekkekıran Mahallesi sınırları içerisinde yer alan Kurt Köprü adıyla tescillenmiş yapıdır (Res. 7). Yürükçal örneğinde olduğu gibi İstavloz Çayı üzerinde bulunan köprünün diğer tarafında Havza sınırları içinde kalan Kayabaşı Mahallesi bulunmaktadır. $86 \mathrm{~m}$. uzunluğa sahip köprü $5 \mathrm{~m}$. genişliğindeki yüksek bir ayak ve yanlardaki sivri kemerli iki gözden oluşmaktadır. İki kemer arasında ve yanlarında olmak üzere sivri kemerli pencere şeklinde toplam üç adet kemer daha bulunmaktadır. Köprünün üzerinde yapılan incelemelerde Roma ve Bizans dönemlerine ait çok sayıda devşirme malzemenin, köprünün inşası sırasında kullanıldığı anlaşılmaktadır. 2007-2009 yılları arasında restorasyon geçiren köprü orijinalliğini kaybetmiştir. ${ }^{9}$ Köprünün Roma temelleri üzerine kurulduğu ifade edilmesine karşın ${ }^{10}$ herhangi bir kalıntı tespit edilememiştir.

Üçüncü köprü; Vezirköprü merkezinin $13 \mathrm{~km}$. güneydoğusunda, Havza'ya giden yolun sağında bulunan Köprübaşı Mahallesi'nde bulunmaktadır. Burada günümüzde kullanılan bir köprü ve eski bir köprünün ayaklarına ait kalıntılar tespit edilmiştir (Res. 8). Bu köprü de diğerleri gibi mahallenin hemen yanı başından geçen İstavloz Çayı üzerinde bulunmaktadır. Kuzey-güney yönlü olarak yapılmış olan köprü üzerinde farklı dönemlerde yapılmış birçok eklentiler görülmektedir. En son eklentinin 1996'da gerçekleşen sel sonrasında eklenen betonarme bir ayak olduğu anlaşılmaktadır. Yüksekliği 4,7 m. olan köprünün en geniş ayak aralığı 15 m.'dir. Orijinal ayakların geniş̧liği 3 m.'dir. Köprünün ayaklarının alt sıralarında daha erken bir döneme ait kaplama levhaları hala görülebilmektedir. Zemin kısmında ayaklar altına yerleştirilen taş blokları yer yer korunmuştur. Köprünün ayakları arasındaki mesafelerin Roma köprü ayaklarıyla büyük ölçüde uyuşması mevut köprünün daha önceden var olan bir Roma köprüsü üzerine inşa dilmiş olabileceği kanaatini oluşturmaktadır. Köprünün hemen yukarısında ise moloz-taş örgülü horasan harçlı başka bir köprünün ayaklarına ait kalıntılar görülmektedir.

\subsection{Sarnıçlar}

Bölgenin coğrafi özelliklerine paralel olarak kalelerde su ihtiyacını karşılamak için kayalara oyulmuş sarnıçlara yer verilmiştir. Bu tip sarnıçlara verilebilecek örneklerden biri Özyörük

\footnotetext{
8 Tønnes Bekker-Nielsen, - Rainer M. Czichon, "Ancient Roads and Bridges of the Vezirköprü District”, $\underline{K}$. Landscape Dynamics and Settlement Patterns in Northern Anatolia during the Roman Byzantine Period (Eds. K. Winther-Jacobsen, L. Summerer): Stuttgart 2015b, s. 299-300.

${ }^{9}$ F. Meral Halifeoğlu - Halide Sert - Süheyla Yılmaz, "Tarihi Kurt Köprüsü (Mihraplı Köprü, Vezirköprü) Restorasyonu Proje Ve Uygulama Çalışmaları”, METU JFA /2, 2013, s. 81-104.

${ }^{10}$ Bekker-Nielsen-Czichon 2015b, agm, s. 295.
} 
Mahallesi'nde yer alan $35 \mathrm{~m}$. yükseklikteki kayalık dik bir yamaç üzerine inşa edilen kalede tespit edilmiştir. $15 \times 15$ m.' lik düz bir platform oluşturan kalenin üzerinde, üç adet sarnıç tespit edilmiştir. Fiziki imkânsızlıklardan dolayı yalnızca birisinin ölçüsünün alınabildiği birinci sarnıcın batı duvarı $473 \times 60 \mathrm{~cm}$. ölçülerinde ve $110 \mathrm{~cm}$. yüksekliğindedir. Güney duvarı ise, $300 \times 60 \mathrm{~cm}$. ölçülerinde ve $70 \mathrm{~cm}$. yüksekliğindedir. Kuzey duvarı 106x60 cm. ölçülerinde ve $65 \mathrm{~cm}$. yüksekliğindedir. Ana kaya sarnıcın doğu duvarı olarak kullanılmışır. Sarnıcın zemini sıkıştırılmış harçlı olup, üzeri ve duvarları sıvalıdır.

\section{Yerleşimler}

Araştırmalarımız yerleşimlerin büyük oranda yamaçlar üzerine kurulduğunu göstermektedir. Vezirköprü'nün dağlik ve engebeli yüzey şekilleri bu tip yerleşim yerlerini ön plana çıkarmış olmalıdır. 2018 yılı çalışmaları sırasında 16 adet yamaç yerleşimi tespit edilmiştir.

\subsection{Yamaç Yerleşimleri}

İlk yamaç yerleşimi Çekalan Mahallesi Kocakarıpınarı Mevkii’nde tespit edilmiştir (Res. 9). Yolun hemen altında yer alan yerleşim, günümüzde tarla olarak kullanılan bir arazi üzerinde bulunmaktadır. Yapılan incelemelerde üzerinde Demir Çağı'ndan başlamak üzere Roma ve Geç Roma dönemlerine ait dağınık şekilde seramik parçaları tespit edilmiştir. Yerleşim üzerinde herhangi bir mimari kalıntıya rastlanmamıştır. Yine aynı mahallenin Köyaltı Mevkii'nde, Kocakaya Yamaç yerleşimi bulunmaktadır (Res. 10). Tescil kaydı bulunan yerleşim Çekalan Mahallesi'nin $300 \mathrm{~m}$. güneyinde, Acısu Deresi'nin yanında yer almaktadır. Tarla olarak kullanılan yamaç üzerinde dağınık bir şekilde Tunç, Demir, Hellenistik, Roma ve Bizans dönemlerine ait çok yoğun bir seramik buluntusuna rastlanmıştır. Yerleşime ait herhangi bir mimari kalıntı tespit edilememiştir.

Üçüncü yerleşim Çalköy Baykuşkaya Mevkii'nde, İstavloz Çayı'nın hemen yamacında bulunmaktadır (Res. 11). Yamaç üzerinde Roma ve Bizans dönemlerine ait çok sayıda seramik, kiremit ve pithos parçaları tespit edilmiştir. Yamacın üst kısmında 4x2.5 m. ölçülerinde, kare planlı olduğu anlaşılan bir Bizans yapısı bulunmaktadır. Yapının, üç sırası izlenebilen moloz taş örgülü, iki kenar duvarı görülmektedir. Bu alanın yukarısında bulunan üç adet taş sandık mezar ve aynı mevkide metruk bir evin bahçesinde, ters bir şekilde gömülmüş olan Bizans dönemine ait mermer sütun başlığı da aynı şekilde bu yerleşim ile ilişkili olmalıdır.

Dördüncü yerleşim Çalköy’den Yürükçal yönüne giden yolun sol tarafında, mahallenin üst kısmında (kuzey-doğu yamacında) köylüler tarafından Gavurevi Mevkii olarak adlandırılan yerde bulunmaktadır (Res. 12). Yamaç yerleşimi üzerinde Yürükçal yolunun üstünden başlamak üzere, Demir ve Ortaçağ'a tarihlenen yoğun bir seramik buluntusu gözlenmiştir. Bu seramik buluntusunun yerleşimin aşağısından geçen İstavloz Çayı'na kadar uzandığı görülmektedir. Yerleşimin uç kısmında günümüzde taş ocağı bulunmaktadır.

Beşinci yerleşim İstavloz Çayı'nın üzerindeki bir yamaç üzerine kurulan Yürükçal Mahallesi'nin Bidene Mevkii'nde (Gavur Yerleşimi), günümüzde tarla olarak kullanılan arazi üzerinde bulunmaktadır (Res. 13). Alanda yapılan incelemelerde Ortaçağ'a ait çok yoğun bir seramik buluntusunun gözlenmesi buranın bir Ortaçağ yerleşimi olduğunu ortaya koymaktadır.

Altınc1 yerleşim Akören Mahallesi'ne giden yolun $60 \mathrm{~m}$. kuzeyinde, tescilli Dökmetepe Tümülüsü'nün 200 m. doğusunda, Tevekleşme Mevkii'nde bulunmaktadır (Res. 14). Yamaç yerleşimi üzerinde Demir, Roma ve Bizans dönemlerine ait çok sayıda seramik buluntusu tespit edilmiştir. Yerleşimin hemen yukarısında bulunan alanda taş sandık mezarlar ve tümülüsün bulunmuş olması burada yoğun bir yerleşim olabileceğinin kanıtı olarak değerlendirilmektedir. Ayrıca mezarların bulunduğu yamacın $700 \mathrm{~m}$. kuzeydoğusunda taş ocağı işletmesi yer almakta

to


olup, köylüler tarafından burada çok sayıda mermer mimari parça çıktığı ve işletmenin temeline gömüldüğü ifade edilmektedir. Akören Mahallesi içinde bulunan çok sayıda devşirme sütun başlığ 1 ve mimari blok da bölgede önemli bir yerleşime işaret etmektedir.

Yedinci yerleşimimiz Vezirköprü merkezinin $4 \mathrm{~km}$. doğusunda bulunan Hacıkurt Mahallesi'nde, köylüler tarafından Kilisekaya Mevkii olarak adlandırılan alanda yer almaktadır (Res. 15). Yerleşim mahallenin kuzey batısında $16 \mathrm{~m}$. yüksekliğindeki sarp kayalık bir alan üzerinde bulunmaktadır. Yapılan araştırmada kayalık üzerinde her hangi bir mimari yapılaşma saptanamamakla birlikte Tunç, Demir, Hellenistik, Bizans ve Ortaçağ dönemlerine ait seramik buluntuları gözlemlenmiştir. Köylüler tarafından kayalığın kuzey tarafında daha önce mezarlar olduğu ifade edilmiş olmasına karşın herhangi bir mezara rastlanmamıştır.

Vezirköprü merkezinin 19 km. kuzeydoğusunda bulunan Kaplancık Mahallesi’nde üç adet yerleşim yeri tespit edilmiştir. Bunlardan ilki Şahinkaya Kanyonu'nun bir uzantısı olan Kaplancık Kanyonu içinde, Bedesten Mevkii olarak adlandırılan yerde bulunmaktadır (Res. 16). Kaplancık Mahallesi'nin yaklaşı $2 \mathrm{~km}$. güneybatısında bulunan yerleşime, ancak Kaplancık tarafından teknelerle ulaşılmaktadır. Yerleşimin Kaplancık tarafındaki kayalıklara olan mesafesi 190 m.'dir. Kanyonun iki yakası arasındaki mesafe ise 72 m.'dir. İki kayalığın arası barajın suyla dolmasından sonra oldukça derinleşmiştir. Şu an derinliğin en az $50 \mathrm{~m}$. olduğu tahmin edilmektedir. Köylüler tarafından önceleri dere yatağından kayaya oyulmuş merdivenlerle çıkışın sağlandığı ifade edilmiş olmasına karşın günümüzde görülememektedir. Doğal bir kayalık alan içine inşa edilen yerleşim kuzey-güney yönünde $30 \mathrm{~m}$., doğu-batı yönünde $20 \mathrm{~m}$. ölçülerindedir. Günümüzde de görülebilen moloz taş örgülü $30 \mathrm{~m}$.' lik istinat duvarı kuzey-güney yönünde inşa edilmiştir (Res. 17). Odaların üzeri toprakla örtülü olduğu için ölçü alınamamıştır. Doğuya doğru bakan yerleşimin aşağı kısımlarında kerpiç kalıntıları izlenebilmektedir. İstinat duvarından suya kadar olan alt kısım yoğun bitki örtüsü ve taşlarla kaplı olduğu için mimari doku tespit edilememiştir. Üzerinde yapılan incelemede yoğun olarak Roma Çağı seramiği olmak üzere Hellenistik ve Demir Çağlarına ait çok sayıda seramik tespit edilmiştir. İkinci yerleşim Kaplancık Yerleşimi'nin $500 \mathrm{~m}$. güneyinde, Harmankaya olarak adlandırılan mevkide yer almaktadır (Res. 18). Kaplancık Kanyonu'nun kenarında bulunan yerleşim üzerinde Tunç, Demir ve Roma Çağı'na ait seramik buluntusu tespit edilmiştir. Köylüler tarafından sular çekildiğinde bazı yapıların ortaya çıktığı ifade edilmiştir. Üçüncü yerleşim Oluklu Mevkii'nde (Gavur Oluklusu) bulunmaktadır (Res. 19). Yerleşim; içinde şapel, duvar kalıntıları ve nekropol alanının da olduğu geniş bir alana yayılmış durumdadır. Alanda görülen Ortaçağ'a ait şapel yaklaşık $14.5 \times 9$ m. ölçülerinde olup yerel taştan yapılmıştır. Günümüzde kuzey duvarının bir kısmı ve doğuya bakan apsisin genel hatları izlenebilmektedir. Şapele ait işlenmemiş küçük kaba taşlar yapının içine ve çevresine yayılmış durumdadır. Şapelin olduğu yerin $10 \mathrm{~m}$. güneyinden itibaren Kabalı Mahallesi sınırı başlamaktadır. Kabalı ve Kaplancık Mahallelerinin sınırlarının birleştiği noktada bulunan Oluklu Mevkii'inde yer alan yamaç yerleşimine ait duvar kalıntıları geniş bir alana yayılmış durumdadır. Yerleşim alanının kuzey tarafının nekropol olarak kullanıldığı anlaşılmaktadır. Alanda yapılan incelemelerde Demir, Roma, Bizans ve yoğun olarak Ortaçağ'a ait olmak dağınık halde çok sayıda seramik buluntusu tespit edilmiştir.

On birinci yerleşim Vezirköprü merkezinin $9 \mathrm{~km}$. güneydoğusunda, Havza-Vezirköprü yolunun $25 \mathrm{~m}$. kuzeyinde, Meşeli Mahallesi'nin $1 \mathrm{~km}$. kuzeybatısındaki Ömer (Taşlık) Mevkii'nde bulunmaktadır (Res. 20). Yerleşim üzerinde Roma ve Ortaçağ dönemlerine tarihlendirilen birçok seramik buluntusu tespit edilmiştir. Mahallenin girişinin hemen sağında mezarlığın yanındaki çeşme üzerinde devşirme olarak kullanılmış mil taşı ve sütun 
bulunmaktadır. Ayrıca Mahalleye giren yolun $5 \mathrm{~m}$. güneyinde, Meşeli İlköğretim Okulu bahçesinin kenarında da atılmış olarak, biri 2 ye ayrılmış 2 adet mil taşı bulunmaktadır. ${ }^{11} \mathrm{Bu}$ mil taşları ve yerleşim yerinde bulunan Roma dönemi seramikleri antik kentin sınırlarını belirleme noktasında oldukça önemli verilerdir.

On ikinci yerleşim Vezirköprü merkezinin $13 \mathrm{~km}$. güneyinde bulunan Tepeören Mahallesi, Mezarlık Mevkii'nde yer almaktadır (Res. 21). Mezarlığın $100 \mathrm{~m}$. batısında yer alan yerleşim üzerinde; Hacıbey Deresi'ne kadar uzanan geniş bir alanda Demir, Geç Demir, Roma ve Ortaçağ dönemine ait çok sayıda seramik tespit edilmiştir. Aynı mahallenin Taşlıpınar (Ağırtarla) Mevkii'nde de ikinci bir yamaç yerleşimi tespit edilmiştir (Res. 22). Yerleşim üzerinde de yine Mezarlık Mevkii'nde olduğu gibi Demir, Geç Demir ve Ortaçağ seramikleri ve çok sayıda kaçak kazı çukuru bulunmuştur. Tepeören Mahallesi içinde yapılan araştırmalarda çok sayıda mimari yapı elamanı, işlik ve mezar stelinin bulunmuş olması bölgede yoğun bir yerleşime işaret etmektedir.

On dördüncü yerleşim Vezirköprü merkezinin $13 \mathrm{~km}$. güneydoğusunda bulunan Boğazkoru Mahallesi, Maltepe Mevkii'nde, bulunmaktadır (Res. 23). Maltepe Yamaç Yerleşimi olarak tescilli olan yerleşimin en yüksek noktasında, Maltepe Tümülüsü yer almaktadır. Yerleşim ortasından geçirilen tarla yolu nedeniyle ikiye ayrilmıştır. Yolun sağ tarafında kalan alan köylüler tarafından Ören Mevkii olarak adlandırılmakta olup, Maltepe Yamaç Yerleşiminin devamı niteliğindedir. $200 \mathrm{~m}^{2}$ lik geniş bir alana yayılmış durumda olan yerleşim üzerinde; Demir, Geç Demir, Roma ve Ortaçağ dönemlerine tarihlenen çok sayıda seramik tespit edilmiştir. Mahallenin içinde yapılan araştırmalar sırasında Köy Konağı'nın bulunduğu kuzeydoğu-kuzeybatı yönünde uzanan kayalık tepe üzerinde kayaya oyulmuş 6 adet mezar, mahallenin girişinde çeşme üzerinde mezar steli, yazıtlı stel parçaları, çok sayıda sütun, işlik, lahit ve mimari yapı parçaları, Boğazkuru Mahallesi'nde önemli bir Roma yerleşimi bulunduğunu ortaya koymaktadır.

On beşinci ve son yerleşim yerimiz Vezirköprü merkezinin $13 \mathrm{~km}$. güneydoğusunda bulunan Tekkekıran Mahallesi'nin 1,5 km. güneydoğusunda, Kale Mevkii olarak adlandırılan alanda bulunmaktadır (Res. 24). Günümüzde tarım arazisi olarak kullanılan ve yaklaşık $200 \mathrm{~m}$. genişliğe sahip bir alanda bulunan yerleşim üzerinde; Demir, Geç Demir, Roma, Selçuklu, Bizans ve Ortaçağ dönemlerine ait çok yoğun bir seramik buluntusu tespit edilmiştir.

\subsection{Höyükler}

Vezirköprü ve çevresinde yüzey şekillerinin çok engebeli ve kayalık oluşu höyük tipi yerleşim yerlerine çok fazla imkan vermemiştir. Çalışmalar sırasında iki adet höyük tespit edilmiştir. Bunlardan ilki Çalköy Mahallesi, Kayalı Mevkii'nin kuzeyinde bulunan Camii Tepesi Höyüğü'dür (Res. 25). Tescilli olan höyük $16 \mathrm{~m}$. yüksekliğinde ve yaklaşık $80 \mathrm{~cm}$. çapındadır. Höyüğün ortasından yol geçirildiği için ikiye bölünmüştür. Bir kısmı da üzerine yapılan ahır, kümes vb. yapılardan dolayı tahrip edilmiştir. Höyüğün yayılım alanı İstavloz Çayı'na kadar uzanmaktadır. Üst kısmında ise, mezarlık alanı bulunmaktadır. Höyük üzerinde Tunç, Demir, Roma ve Bizans dönemlerine ait seramik buluntusu tespit edilmiştir. Höyükten çıkarıldığı ifade edilen üç parça mermer yapı bloğu ve hemen bitişiğindeki bir meskenin bahçesinde bulunan sütun kaideleri ve temek blokları höyükte erken dönemlerden geç dönemlere kadar bir yerleşim olduğunun önemli ipuçları olarak görülmüştür.

\footnotetext{
${ }^{11}$ David French, Roman Roads and Milestones of Asia Minor, Fasc. 2.1: An Interim Catalogue of Milestones (British Institute of Archaeology at Ankara Monograph, 9; British Archaeological reports, International Series, 392/I), Oxford 1988, nos. 892-893.
}

\section{History Studies}


İkinci höyük Vezirköprü merkezinin $11 \mathrm{~km}$. güneydoğusunda, Yarbaşı Mahallesi’nin, 400 m. kuzeyinde bulunmaktadır (Res. 26). Tescilli olan höyük kuzeybat1-güneydoğu yönünde uzanmakta olup, güney ucu İstavloz Çayına kadar uzanmaktadır. Birçok kaçak kazı çukuru bulunan höyük üzerinde; açılan çukurlar içinde moloz taş örgülü duvarlar ve tonozlar izlenebilmektedir. Höyüğün güney tarafındaki yamaç üzerinde $4 \mathrm{~m}$.'lik kısmı izlenebilen geç dönem duvar sırasından itibaren, Demir Çağı'ndan başlayan seramik kalıntılarının yerleşimin güneyinden aşağıya, İstavloz Çayı'na doğru akmış olduğu izlenmektedir. Yerleşimin genelinde yapılan incelemede ise Demir, Hellenistik, Roma ve Ortaçağ'a tarihlenen seramik buluntuları tespit edilmiştir.

\subsection{Yapı Kalıntıları}

Çalışmalar sırasında işlevi tam olarak tespit edilememiş yapı kalıntıları tespit edilmiştir. Bunlardan ilki Hacıkurt Mahallesi'nin $1 \mathrm{~km}$. batısında bulunan Hozan Mevkii'nde bulunmaktadır. Duvar işçiliği ve malzemesinden Bizans dönemine ait olduğu anlaşılan yapı; kare planlı olup $13 \times 13 \mathrm{~m}$. ölçülerindedir (Res. 27). Tek sırası görülebilen yapının duvar kalınlığı ölçülememiştir. Yapının güney duvarı $13 \mathrm{~m}$., doğu ve batı duvarları ise $3 \mathrm{~m}$.'ye kadar takip edilebilmektedir. Hacıkurt Mahallesi'nde ve mahallenin girişindeki Hacıkurt Türbesi içinde yapılan incelemelerde bulunan çok sayıdaki devşirme mermer sütun ve mimari blok, bölgedeki bir yerleşime işaret etmektedir.

İkinci yapı kalıntısı Çekalan Mahallesi'nin yaklaşık $1.5 \mathrm{~km}$. kuzeyinde Kocakarıpınarı Mevkii'nde bulunmaktadır. Alanda yapılan incelemelerde Bizans dönemine ait moloz taş örgülü bir duvar kalıntısı tespit edilmiştir (Res. 28). 14.40x7 m. ölçülerinde ve L biçiminde devam eden duvar örgüsünün ölçülebilen kalınlığı $105 \mathrm{~cm}$.' dir. Dışı tek sıra moloz taş örgülü duvarın, iç dolgusu görülememektedir. Yakınlarında bulunan üç adet taş sandık mezardan buranın olasılıkla bir konuta ait olabileceği düşünülmektedir.

Üçüncü yapı kalıntısı Vezirköprü merkezinin 6 km. güneyinde Çamlıca Mahallesi'nin 1.5 km. kuzeydoğusunda, Kızılcaören'e giden tarla yolunun kenarında, Ötegeçe Mevkii olarak adlandırılan yerde bulunmaktadır. Alanda yapılan incelemede Roma dönemine ait bir adet mermer lahit kapağ 1 ve arşitrav bloğu bulunmuştur (Res. 29). Yapılan incelemede söz konusu malzemelerin mevcut alandan çıkartılmış olduğunun anlaşılması ve mahallenin içindeki çeşmenin aynalığ 1 üzerinde yer alan tavan kaseti ile bir evin bahçesinde bulunan arşitrav bloğu bölgede bir Roma yerleşiminin olduğuna işaret etmektedir.

Dördüncü yapı kalıntısı Köprübaşı Mahallesi, Eşebaba Mevkii'nde tespit edilmiştir (Res. 30). Havza yolunun 16. km.' sinde, yolun yaklaşı $100 \mathrm{~m}$. batısında bulunan yerleşim üzerinde seramik buluntusuna rastlanmamış olmakla birlikte, bir yapının duvar kalıntıları izlenebilmektedir. Yamaç üzerinde bulunan yapının kuzey-güney yönünde dikdörtgen bir plana sahip olduğu ve zemininin sıkıştırılmış kireç olduğu anlaşılmaktadır.

\section{Mezar Yapıları}

Burada tespit edilen 15 adet tümülüsün çapları yaklaşık 10-80 m., yükseklikleri ise yaklaşık 1-21 m.'dir. Bilimsel kazılarla ortaya çıan ve kaçak kazılarla tahrip edilmiş olanlar incelendiğinde genel olarak tümülüslerin, mezar odası ve ön oda olmak üzere iki bölümden oluştukları görülmektedir. Dromos ve mezar odası tamamen kesme taştan inşa edilen mezarların üzerinin taş ve toprakla suni bir tepecik şeklinde örtülmüş olduğu ya da yığma toprak altında yer alan mezar odasının, konglomera-aglomera tortul kayaca oyularak yapıldığı 
anlaşılmaktadır. ${ }^{12}$ Vezirköprü/Oymaağaç Höyük’te gerçekleştirilen kazılarda Roma Dönemi’ne ait çoklu gömü yapılan taş sandık tipi mezarlara rastlanmıştır. ${ }^{13}$ Bizim tespit ettiğimiz 8 adet taş sandık mezarın tamamı soyulmuştur. Bu tip mezar örneklerine Amisos Antik kentinin nekropol alanında da rastlanmıştır. Bunlar daha çok konglomera tortul kayaçlara sandık şeklinde oyulup, gömü gerçekleştirildikten sonra üstlerinin çatı kiremidi veya tuğla ile kapatılmasıyla oluşturulan mezar tipleridir. ${ }^{14}$ Araştırmamız sırasında tespit ettiğimiz kayaya oyulmuş 6 adet kaya oygu mezarı da derinlikleri ve boyutları farklı olmakla birlikte, aynı tip mezar geleneğini devam ettirmektedir. Bu mezarlarda kapak olarak sal taşları kullanılmış olup tamamının soyulmuş olduğu görülmektedir. Bu tip mezarların dışında çalışmalarımız sırasında 10 adet mermer lahit teknesine ve kapağına, 1 adet kaya mezarına ve 7 adet mezar steline rastlanmıştır.

\subsection{Tümülüsler}

Vezirköprü merkezinin $11 \mathrm{~km}$. kuzeydoğusunda bulunan Çekalan Mahallesi'nin yaklaşık 500 m. kuzeyindeki yamaç üzerinde, Derenöz Tümülüsü I olarak adlandırdığımız küçük çaplı bir tümülüs tespit edilmiştir. Tarla olarak kullanılan arazi içinde bulunduğu için, tümülüsün üst kısmı büyük ölçüde tesviye edilmiştir (Res. 31). Köylüler tarafından önceleri $3 \mathrm{~m}$. yükseklikte olduğu ifade edilen tümülüsün, şu an ki korunabilen yüksekliği $1 \mathrm{~m}$. olup, çap1 yaklaşık 25 m.'dir. I. Tümülüsün $50 \mathrm{~m}$. aşağısında, aynı mevkide ikinci bir tümülüs daha bulunmuştur (Res. 32). Derenöz Tümülüsü II olarak adlandırdığımız bu tümülüste birincisinde olduğu gibi tarım arazinde bulunmakta olup, büyük ölçüde üst kısmı tesviye edilmiştir. $1 \mathrm{~m}$. yüksekliği korunmuş olan tümülüs yaklaşık $20 \mathrm{~m}$. çapındadır. Yine aynı yerde, ikinci tümülüsün $50 \mathrm{~m}$. aşağısında, mahallenin yaklaşık $430 \mathrm{~m}$. kuzeyinde Derenöz Tümülüsü III olarak adlandırdığımız üçüncü bir tümülüs daha bulunmuştur. Üst kısmı tesviye edilen tümülüs $1 \mathrm{~m}$. yüksekliğinde ve 20-25 m. çapındadır (Res. 33). Her üç tümülüsün çevresinde Ortaçă̆'a ait çok sayıda seramik buluntusu gözlemlenmiştir. Çekalan Mahallesi'nde bulunan dördüncü tümülüs Armutarası Mevkii'nde bulunmaktadır. Merkezin $1 \mathrm{~km}$. kuzeyindeki tescilli tümülüs yaklaşık 20 m. çapında olup, 2 m. yüksekliğe kadar olan kısmı korunabilmiştir (Res. 34). Büyük ölçüde tahrip edilmiş olan tümülüs üzerinde, köylüler tarafindan p.t. unguentaryum bulunduğu ve müzeye teslim edildiği ifade edilmiştir. Aynı mevkide tescilli ikinci bir tümülüs daha bulunmaktadır (Res. 35). Birinci tümülüsün yaklaş1k $100 \mathrm{~m}$. doğusunda bulunan bu tümülüs yaklaşık $15 \mathrm{~m}$. çapında olup, korunabilen yüksekliği 2 m.'dir.

Altıncı tümülüs tescilli olup Yürükçal Mahallesi’nin $2 \mathrm{~km}$. güneybatısında bulunmaktadır (Res. 36). 15 m. yüksekliğinde ve $80 \mathrm{~m}$. çapında olan tümülüs üzerinde birçok kaçak kazı çukuru bulunmaktadır.

Yedinci tümülüs Vezirköprü merkezinin $8 \mathrm{~km}$. güneydoğusundaki Bahçekonak Mahallesi'nin, 3 km. kuzeybatısında, Kületek Mahallesi'nin 2 km. güneyinde İkiztepe olarak adlandırılan mevkide bulunmaktadır (Res. 37). Tescilli olan tümülüsün (tarafımızca İkiztepe I Tümülüsü olarak adlandırılmıştır) korunmuş yüksekliği $4 \mathrm{~m}$., çapı ise $30 \mathrm{~m}$.'dir. Köylüler tarafından yüksekliğinin $15 \mathrm{~m}$. kadar olduğu ancak sonrasında iş makinasıyla tarım arazisi olarak kullanılmak üzere tesviye edildiği ifade edilmiştir. Tümülüsün kuzeybatı eteği derin bir

\footnotetext{
${ }^{12}$ Mahmut Akok, “Samsun İli Havza İlçesi’nin Lerdüge Köyü’nde Bulunan Tümülüsler”, Belleten XII/48, 1948, s. 835-853; Mehmet Özsait, "2002 Yılı Samsun-Amasya Yüzey Araştırmalarının İlk Sonuçları”, 21. Araştırma Sonuçları Toplantısı 2, 2003, s. 273-284; Sümer Atasoy - Muhsin Endoğru - Şevket Dönmez, "Samsun-Baruthane Tümülüsleri Kurtarma Kazısı", Anadolu Araştırmaları Dergisi XVIII/2, 2005, s. 153-165; Serdar Ünan, "Samsun/Dondortepe (Hacı İsmail) Tümülüsü”, Masrop E-Dergi 4, 2009, s. 3-4; “Tunç Çağı'ndan Roma Dönemi'ne Amisos ve Çevresinde Yer Alan Mezar Tipleri ve Ölü Gömme Adetleri Üzerine Genel Bir Değerlendirme”, Güneş Karadeniz'den Doğar Sümer Atasoy'a Armağan Yazllar, (Ed. Şevket Dönmez). Ankara 2013. s. 394.

${ }^{13}$ Czichon 2007, agm, s. 4; 2008b, agm, s. 187-196.

${ }^{14}$ Ünan 2013, agm, s. 391.
}

to


şekilde kesilerek tarlaya dahil edilmiştir. Aynı mevkide İkiztepe II Tümülüsü olarak adlandırdığımız tescilli ikinci Tümülüs daha bulunmaktadır (Res. 38). 1. tümülüsün $200 \mathrm{~m}$. güneyinde bulunan bu tümülüsün 2 m.'lik kısmı korunabilmiş olup, ölçülebilen çapı 25-30 m.'dir. Üzeri birincisinde olduğu gibi tarım arazisi olarak kullanılmak üzere tesviye edilmiş ve güneydoğu eteği derin bir şekilde kesilerek tarlaya dahil edilmiştir.

Sekizinci tümülüs Çalköy'ün $2 \mathrm{~km}$. güney doğusunda, yolun $25 \mathrm{~m}$. güneyinde bulunmaktadır (Res. 39). Tescilli olan tümülüs $10 \mathrm{~m}$. yüksekliğinde ve $50 \mathrm{~m}$. çapındadır. Tümülüs güney eteğinden kuzeye doğru, tam ortasından $35 \times 20 \mathrm{~m}$. ölçülerinde $10 \mathrm{~m}$. derinliğinde yarılmıştır. Aynı şekilde kuzey tarafı da (yola bakan taraf) doğu batı yönünde $27 \times 33 \mathrm{~m}$. ölçülerinde ve $10 \mathrm{~m}$. derinliğinde yarılarak tahrip edilmiştir.

Dokuzuncu tümülüs Vezirköprü merkezinin 4 km. kuzeyindeki Akören Mahallesi’nin 2 km. doğusunda, Cami Tepe Höyügü̆'nün $300 \mathrm{~m}$. kuzeybatısında bulunmaktadır (Res. 40). Dökmetepe olarak tescillenen tümülüs Çorak Dere'nin Akçay Deresi'yle karıştığı yerin $50 \mathrm{~m}$. kuzeyinde bulunmakta olup batıda Adatepe'ye bakmaktadır. $21 \mathrm{~m}$. yüksekliğinde ve $80 \mathrm{~m}$. çapında olan tümülüs üzerinde $6 \times 10 \mathrm{~m}$. ölçülerinde $1.70 \mathrm{~cm}$. derinliğinde kaçak kazı çukuru bulunmaktadir.

Onuncu tümülüs Akören Mahallesi, Kabaktepe Mevkii'nde bulunmakta olup tarafimızca Kabaktepesi Tümülüsü olarak adlandırılmıştır (Res. 41). $21 \mathrm{~m}$. yüksekliğinde, $10 \mathrm{~m}$. çapında olan tümülüs İstavloz Çayı'nın batısında, Ali Hıdır Değirmeni'nin 200 m. batısında, Akören değirmen yolunun $30 \mathrm{~m}$. kuzeyinde kayalık bir alan üzerinde bulunmaktadır. Araziye hakim bir noktada yer alan tümülüs üzerinde $7 \times 13 \mathrm{~m}$. ölçülerinde, $3 \mathrm{~m}$. derinliğinde kaçak kazı çukuru bulunmaktadır.

Volume 12

Issue 2

A Tribute

to Assoc.

Prof. Dr.

İlknur

Mangir

Karagöz,

April

2020

On birinci tümülüs Vezirköprü merkezinin $13 \mathrm{~km}$. güneydoğusunda, Havza'ya giden yolun sağında bulunan Köprübaşı Mahallesi'nde, Camitepe Mevkii'nde bulunmaktadır (Res. 42). 90'lı y1llarda üzerinde bir cami bulunduğu için bu isimle anılan tepe üzerinde yer alan tümülüs tarafımızca Camitepe Tümülüsü olarak adlandırılmıştır. $7 \mathrm{~m}$. yüksekliğinde ve $20 \mathrm{~m}$. çapındadır.

On ikinci tümülüs Vezirköprü merkezinin $13 \mathrm{~km}$. güneydoğusunda bulunan Boğazkoru Mahallesi, Maltepe Mevkii'nde bulunan Maltepe Tümülüsü'dür (Res. 43). Tescil kaydı bulunan tümülüs mahallenin $300 \mathrm{~m}$. doğusunda bulunmaktadır. Yerleşimin tam üstüne konumlandırılmış tümülüs İstavloz Çayı'nın $2 \mathrm{~km}$. güneyinde yer almaktadır. $10 \mathrm{~m}$. yüksekliğinde, yaklaşık $70 \mathrm{~m}$. çapındadır. Üzerinde birçok kaçak kazı çukuru bulunan tümülüsün çevresinde Orta Çağ'a tarihlenen seramikler tespit edilmiştir.

On üçüncü tümülüs Vezirköprü merkezinin $13 \mathrm{~km}$. güneydoğusunda Tekkekıran Mahallesi'nin girişinde, mezarlığın doğusunda bulunmaktadır (Res. 44). 10 m. yüksekliğinde, $40 \mathrm{~m}$. çapında olan tümülüs yolun yaklaşık $30 \mathrm{~m}$. uzağındadır. Kuzey tarafı yoğun bitki örtüsüyle kaplı olan tümülüs üzerinde kuzeybatı yönünde uzanan 6 x11 m. ölçülerinde, $4 . \mathrm{m}$. derinliğinde bir kaçak kazı çukuru bulunmaktadır. Tümülüsün mezarlık alanına bakan tarafı tarla olarak kullanılmak üzere tahrip edilmiştir. Aynı mahallenin Aşağıtepe Mevkii'nde ikinci bir tümülüs daha tespit edilmiştir (Res. 45). Tarafımızca Aşağıtepe Tümülüsü olarak adlandırılan tümülüs Aydoğdu Mahallesi'nin 3 km. kuzeydoğusunda, Tekkekıran Mahallesi'nin $1.5 \mathrm{~km}$. batısında ve Tekkekıran yolunun $200 \mathrm{~m}$. güneyinde bulunmaktadır. Tümülüs $7 \mathrm{~m}$. yüksekliğinde ve yaklaşık $30 \mathrm{~m}$. çapındadır. Doğu tarafı $12 \times 20 \mathrm{~m}$. ölçülerinde tahrip edilmiş olan tümülüsün üzeri tarım arazisi olarak kullanılmaktadır.

On beşinci tümülüs Vezirköprü merkezinin $10 \mathrm{~km}$. güneydoğusunda Aydoğdu Mahallesi'nin, Arpalık Mevkii'nde bulunmaktadır (Res. 46). Aydoğdu Mahallesi'nin 2 km. 
kuzeyinde ormanlık bir alanda bulunan, $6 \mathrm{~m}$. yüksekliğe ve $10 \mathrm{~m}$. çapa sahip tümülüsün doğu kenarı 10x5 m. ölçülerinde tahrip edilmiştir. Tepe kısmı da büyük ölçüde aşınmıştır.

\subsection{Mezarlar}

Çalışmalar sırasında tespit edilen mezarlar kaya mezarları, kaya oygu mezarları ve taş sandık mezarlar olmak üzere üç başlık altında değerlendirilmişlerdir.

\subsubsection{Kaya Mezarları}

2018 yılı çalışmaları sırasında bir adet kaya mezarına rastlanmıştır. Kaya mezarı Vezirköprü merkezinin $15 \mathrm{~km}$. kuzeydoğusundaki Özyörük Mahallesi'nde bulunmaktadır (Res. 47). Mahallenin $500 \mathrm{~m}$. güneybatısındaki $35 \mathrm{~m}$. yüksekliğindeki kayalık dik bir yamaç üzerinde bulunmaktadır. Üzerinde kale bulunan kayalık alana yer yer basamaklar yerleştirilmiş dik bir yoldan çıkılmaktadır. Kaya mezarı dikdörtgen bir giriş ve beşik tonoz örtülü bir mezar odası olmak üzere iki odadan oluşmaktadır (Res. 48). İçerisine bir kline yerleştirilmiş olan mezar odasının dromosunu kapatmak için geniş bir silme, kuzey ve batı duvarlarında muhtemelen ahşapla kapatılması için yuvalar mevcuttur. Mezara girişte ise, kapı sövesi ve kilit yuvası mevcuttur. Mezar odasının ön odası $1.64 \times 2.66 \mathrm{~cm}$. ölçülerinde ve $2.70 \mathrm{~cm}$. yüksekliğindedir. Mezarın giriş kısmı ise 42x90 cm. ölçülerinde ve $90 \mathrm{~cm}$. yüksekliğindedir. Mezar Odası yaklaşık $2.54 \times 2.11 \mathrm{~cm}$. ölçülerinde ve $1.90 \mathrm{~cm}$. yüksekliğindedir.

\subsubsection{Kaya Oygu Mezarlar}

Vezirköprü merkezinin $13 \mathrm{~km}$. güneydoğusunda bulunan Boğazkoru Mahallesi Köytepesi Mevkii'nde birçok kaya oygu mezarı tespit edilmiştir. Mezarlar köy konağının bulunduğu, kuzeydoğu-kuzeybatı yönünde uzanan, 150x50 m. ölçülerindeki kayalık bir tepe üzerinde bulunmaktadır (Res. 49). Üzerine köy konağı yapılırken kayalık alan düzleştirilmiştir. Öncüleri daha fazla mezarın bulunduğu ifade edilen kayalık alan üzerinde, günümüzde 6 adet mezar tespit edilebilmiştir.

1. Mezar; 200x85 cm. ölçülerinde, $47 \mathrm{~cm}$. derinliğindedir.

2. Mezar; $145 \times 70 \mathrm{~cm}$. ölçülerinde, $41 \mathrm{~cm}$. derinliğindedir.

3. Mezar; 170x83 cm. ölçülerinde, $48 \mathrm{~cm}$. derinliğindedir.

4. Mezar; 230x60 cm. ölçülerinde, $22 \mathrm{~cm}$. derinliğindedir (Res. 50).

5. Mezar; $155 \times 85 \mathrm{~cm}$. ölçülerinde, $26 \mathrm{~cm}$. derinliğindedir.

6. Mezar; 192x86 cm. ölçülerinde, $25 \mathrm{~cm}$. derinliğindedir. Çevrede kırılmış çok sayıda mezar kapağı bulunmaktadır. Kayalık alan üzerinde bulunan seramikler profil vermemektedir. Boğazkoru Mahallesi Köykonağı Mevkii'nde kaya oygu mezarlarının eteğinde bir adet mezar kapağı bulunmuştur (Res. 51).

\subsubsection{Taş Sandık Mezarlar}

Çalışmalar sırasında 8 adet taş sandık mezara rastlanmıştır. İlk üç mezar Çekalan Mahallesi'nin yaklaşık 1. $5 \mathrm{~km}$. kuzeyinde, Kocakarıpınarı Mevkii'nde bulunmaktadır. 8-10 cm. kalınlığındaki sal taşlarından yapılan mezarlar, doğu-batı yönlüdür (Res. 52). 1. mezarın korunabilen uzunluğu $70 \mathrm{~cm}$., genişlik ise $75 \mathrm{~cm}$.'dir. $75 \mathrm{~cm}$. derinliğindeki mezarın yarıs1 tahrip edilmiş olup içinde dağınık bir şekilde kemik buluntuları görülmektedir. 2. mezar büyük ölçüde tahrip olduğu için ölçü vermemektedir. Bu mezarın $5 \mathrm{~m}$. batısında bulunan 3 . mezar ise $70 \mathrm{~cm}$. uzunluğa ve $80 \mathrm{~cm}$. genişliğe sahiptir. $50 \mathrm{~cm}$. derinliğe sahip olan mezar büyük ölçüde tahrip edilmiştir.

Benzer mezarlara Çalköy, Baykuşkaya Mevkii'nde de rastlanmıştır. İstavloz Çayı'nın yaklaşık 85 m. uzağında, Bizans dönemine ait yapı kalıntısının bulunduğu alanın yukarısında, 
üç adet taş sandık mezar bulunmuştur. Doğu-batı yönünde uzanan mezarlardan ilki 190x80 cm. ölçülerinde, $58 \mathrm{~cm}$. derinliğindedir (Res. 53). Diğer iki mezar ise ölçü vermemektedir.

Taş sandık mezarlar içinde diğerlerine göre daha iyi korunmuş durumda bulunan bir örneğe Akören Mahallesi, Tevekleşme Mevkii'nde rastlanmıştır (Res. 54). Akören yolunun $200 \mathrm{~m}$. batısında, Dökmetepe Tümülüsü'nün $400 \mathrm{~m}$. kuzey doğusunda bulunan mezar $182 \times 90 \mathrm{~cm}$. ölçülerinde ve $110 \mathrm{~cm}$. derinliğindedir. Kaba işlenmiş taşlardan yapılmış olan mezarın kapağ bulunmamaktadır. Çevresinde birçok kaçak kazı çukurunun bulunduğu alanda, köylüler tarafından başka mezarların da bulunduğu ifade edilmiş olmasına karşın tespit edilememiştir. Mezarın bulunduğu yamacın $700 \mathrm{~m}$. kuzeydoğusunda taş ocağı işletmesi yer almakta olup, köylülerce buradan çok sayıda mermer mimari parçanın çıktığı ve taş ocağına gömüldüğü ifade edilmiştir.

Diğer bir taş sandık mezar Hacıkurt Mahallesi, Hozan Mevkii’nde, mahallenin $1.5 \mathrm{~km}$. batısında, tarım arazisi üzerinde bulunmaktadır (Res. 55). 200x80 cm. ölçülerinde ve $75 \mathrm{~cm}$. derinlikte olan mezar doğu batı yönlü olarak yapılmıştır. Mezarın uzun kenarlarından biri eksik, kısa kenarlarından biri ise toprağa gömülü vaziyettedir.

\subsection{Mezar Stelleri}

2018 çalışmaları sırasında yazıtlı ve yazıtsız olmak üzere çok sayıda mezar steli tespit edilmiştir. Geniş bir alana yayılmış olan bu mezar stelleri Neoklaudiopolis antik kentinin günümüze ulaşabilmeyi başarmış en önemli belgeleridir. Farklı yapılarda devşirme olarak kullanılan bu mezar stellerinden ilki Vezirköprü merkezinin $4 \mathrm{~km}$. kuzeydoğusunda yer alan Çal Mahallesi'nde bulunmaktadır. Çal Camisi'nin çevre duvarının dış kısmına yatay olarak yerleştirilmiş olan mermer mezar steli $112 \times 55 \mathrm{~cm}$. ölçülerindedir (Res. 56). Üçgen alınlıklı

Volume 12

Issue 2

A Tribute

to Assoc.

Prof. Dr.

İlknur

Mangir

Karagöz,

April

2020 olan mezar steli üzerinde 19 satır Latince yazıt ve altında balta ve orak tasvirleri bulunmaktadır.

İkinci stelimiz Vezirköprü merkezinin 6 km. güneydoğusundaki Kızılcaören Mahallesi’nde bulunmaktadır (Res. 57). Mahalle camisinin avlusunda yer alan stelin Latince yazıtının üzerine sonradan Arapça bir yazıt işlenmiştir. Mezar steli 145x49 cm. ölçülerinde olup eni $22 \mathrm{~cm}$.'dir.

Üçüncü stelimiz Vezirköprü merkezinin 13 km. güneyinde Tepeören Mahallesi’nde, Necati Şahin'e ait evin bahçe duvarı üzerinde bulunmaktadır (Res. 58). 183x55 cm. ölçülerindeki mezar steli üzerinde 15 satırlık yazıt görülmektedir. Aynı mahallede Kamil Pektaş'ın Evi'nde ise $42 \times 23 \mathrm{~cm}$. ölçülerinde, arkasında 11 satır Rumca yazıt, ön kısmında ise haç işlemesi ve mum yakılması için niş bulunan bir mezar steli tespit edilmiştir (Res. 59).

Beşinci stelimiz Vezirköprü merkezinin $13 \mathrm{~km}$. güneydoğusunda Boğazkoru Mahallesi'nin hemen girişindeki çeşmenin aynalığı üzerinde bulunmaktadır (Res. 60-61). 130x66 cm. ölçülerindeki mezar steli üzerinde 15 satır Latince yazıt bulunmaktadır. Aynı mahallede Kamil Erdoğan'a ait samanlığının güney duvarında, ikiye ayrılmış bir durumda bir mezar steli tespit edilmiştir (Res. 62). $1.50 \times 41 \mathrm{~cm}$ ve $2.53 \times 27 \mathrm{~cm}$. ölçülerinde olan parçalar birleştirildiğinde 17 satırlık yazıt oluşturmaktadır.

Yedinci ve oldukça iyi durumda olan son mezar stelimiz Vezirköprü merkezinin $8 \mathrm{~km}$. güneydoğusundaki Bahçekonak Mahallesi'nde Recep Top'un Evi'nin bahçesinde bulunmaktadır. $185 \times 65 \mathrm{~cm}$. ölçülerinde ve $36 \mathrm{~cm}$. kalınlığında ki mezar steli üzerinde 20 satır latince yazit bulunmaktadır (Res. 63). 


\subsection{Lahitler}

Arazi çalışmaları sırasında çok sayıda lahit teknesi ve kapağına rastlanmıştır. Bunların bir kısmı arazide serbest bir şekilde bazılarının ise devşirme olarak farklı yapılarda kullanıldığ görülmektedir. Bunlardan biri Yürükçal Mahallesi, İlköğretim Okulu’nun 100 m. güneyindeki, Hasan Çalışkan'a ait evin bahçesinde bulunmaktadır. Burada 70x47 cm., ölçülerinde, $18 \mathrm{~cm}$. derinliğinde mermer bir ostotek kapağı bulunmuştur (Res. 64). Yürükçal Mahallesi'ne bağlı Hacıkurt Mahallesi içinde de birçok devşirme mimari parça bulunmuştur. Bunlardan biri de $143 \times 82 \mathrm{~cm}$. ölçülerinde, $20 \mathrm{~cm}$. kalınlığındaki bir lahit tabanıdır (Res. 65).

Vezirköprü merkezinin 8 km. güneydoğusunda Bahçekonak Mahallesi’nde, Kaşif Kurt'un arazisi içerisinde 130x62 cm. ölçülerinde ve $30 \mathrm{~cm}$. kalınlığında bir lahit kapağı bulunmuştur (Res. 66). Bir diğer lahit kapağı Vezirköprü merkezinin $6 \mathrm{~km}$. güneyindeki Çamlıca Mahallesi'nin $1.5 \mathrm{~km}$. kuzeydoğusunda Ötegeçe Mevkii'nde, Kızılcaören'e giden tarla yolu üzerinde bulunmuştur (Res. 67). 160x90 cm. ölçülerinde ve $25 \mathrm{~cm}$. kalınlığındaki lahit kapağının ve yanında bulunan arşitrav bloğunun mevcut alandan çıkartıldığı bilinmektedir. Bu da bölgede önemli bir Roma yerleşimi olduğunu göstermesi açısından oldukça önemlidir.

Yapılan araştırmalarda lahit kapaklarının yanı sıra lahit teknelerinin de yoğun bir şekilde varlığı saptanmıştır. Bunlardan ikisi Vezirköprü merkezinin $3 \mathrm{~km}$. güneyindeki Doyran Mahallesi'nin, Aşağıpınarı Mevkii'nde, mahallenin girişindeki çeşmenin üzerinde görülmektedir (Res. 68). Birinci lahit $217 \times 75 \mathrm{~cm}$. ölçülerinde, $50 \mathrm{~cm}$. derinliğinde ve $57 \mathrm{~cm}$. yüksekliğindedir. İkinci lahit ise $182 \times 82 \mathrm{~cm}$. ölçülerinde, $45 \mathrm{~cm}$. derinliğinde ve $53 \mathrm{~cm}$. yüksekliğindedir. Bir diğer lahit teknesi Vezirköprü merkezinin $13 \mathrm{~km}$. güneydoğusunda Boğazkoru Mahallesi, Maltepe Mevkii, yamaç yerleşimi üzerinde görülmektedir (Res. 69). Günümüzde hayvan yalağı olarak kullanılan lahit teknesi 240x84 cm. ölçülerinde, $60 \mathrm{~cm}$. yüksekliğinde ve $40 \mathrm{~cm}$. derinliğindedir.

Vezirköprü merkezinin $5 \mathrm{~km}$. güneydoğusunda Karacaören Mahallesi'nde, mezarlığın kuzeyinde, yolun kenarında birçok mimari parça bulunmaktadır. Bunlardan lahit kapağ1, $197 \times 87 \mathrm{~cm}$. ölçülerinde ve $16 \mathrm{~cm}$. kalınlığındadır (Res. 70). Lahit teknesi ise yalak olarak kullanılmakta olup, 340x61 cm. ölçülerinde ve $50 \mathrm{~cm}$. yüksekliğindedir (Res. 71). Bahçekonak Mahallesi'nde bir tarla içinde bulunan lahit teknesi ise çeşmenin tekne kısmında kullanılmış olup 2.10x92 cm. ölçülerinde ve $50 \mathrm{~cm}$. derinliğindedir (Res. 72).

\section{Sonuç}

Samsun İli Vezirköprü ilçesindeki ilk araştırmalar 70’li yıllara kadar uzanmaktadır. Sonraki yıllarda da Samsun ve çevre ilçelerinde çok sayıda yüzey araştırması yapılmıştır. Ancak bu çalışmalarda Vezirköprü üzerinde çok fazla durulmadığı görülmektedir. Mevut çalışmalar özellikle Hititlerin kutsal şehri olarak kabul edilen Nerik'in lokalize edildiği Oymaağaç ve çevresinde yoğunlaşmıştır. Sonraki süreçte Danimarkalı bir ekip tarafından bölgede çalışmalar yürütülmüş olmasına karşın bunların daha çok mil taşları ve yazıtlar üzerinden gerçekleştirildiği görülmektedir. Samsun İlinde en çok kaçak kazının ve tahribatın olduğu alanların başında şüphesiz Vezirköprü gelmektedir. Samsun Müzesi envanterinde bulunan birçok antik malzemenin Vezirköprü'den getirilmiş olması da bunun en büyük delilidir. ${ }^{15}$ Mevcut envanter kayıtlarının da çok yeterli olmadığı aşikardır. Bu kapsamda bölgenin sağlıklı bir kültür envanterinin çıkarılabilmesi için kapsamlı bir yüzey araştırmasına ihtiyaç duyulmuş ve 2018 yılından itibaren çalışmalara başlanmıştır. 2018 yılı yüzey araştırması, Vezirköprü

\footnotetext{
${ }^{15}$ Akın Temür, "Ein Ohrring mit Sphingenmotiv aus Vezirköprü-Samsun (Nordtürkei)”, Mitteilungen der Deutschen Orient Gesellschaft 148, 2016, s. 165-177.
}

\section{History Studies}


merkezine bağlı 27 köyde gerçekleştirilmiştir. Bu sezon yürütülen çalışmalar özellikle Roma kalıntılarının yoğunlaştığı İstavloz Çayı çevresinde bulunan köylerde gerçekleştirilmiştir. Bu çalışmalar sırasında, tescilli olanlarla birlikte, 3 kale ve 15 yamaç yerleşimi, 2 höyük, 3 adet köprü, 4 adet mimari yapı kalıntısı, 15 tümülüs, 8 taş sandık mezar, 6 kaya oygu mezar, 10 lahit teknesi, 7 adet mezar steli, 1 kaya mezarı, 4 adet mimari yapı kalıntısı, çok sayıda işlik, sütun, sütun başlığ1 ve altlığ1, lahit, mimari yap1 elamanı, mezar stelleri ve mil taşları ayrıntılı bir şekilde araştırılarak kayıt altına alınmıştır. Birçok bölgede tarihlemek amacıyla nitelikli seramiklerden örnekler toplanmıştır. Çok tabakalı yerleşimlerin sayısı azdır. Ele geçen devşirme malzemeler ve seramikler ağılıklı olarak Roma ve Bizans dönemlerine tarihlenmekte olup Karadeniz ve Orta Anadolu ile paralellik arz etmektedir. Çalışmalar sırasında bulunan çok sayıdaki mermer mimari yapı elemanları ve işlikler Neoklaudiopolis Antik Kenti'nin geniş bir alana yayıldığını ve azımsanmayacak bir nüfusa sahip olduğunu göstermektedir. Tespit edilen tümülüs ve yamaç yerleşimlerinde çok sayıda kaçak kazı çukurunun görülmesi bölgede yoğun bir definecilik faaliyetinin yürütüldüğünü ortaya koymaktadır. Tümülüslerden mezar odası açılan bir örneğe rastlanmadığı için kesin bir tarih vermek mümkün görünmemekle birlikte ağırlıklı olarak Roma dönemine ait olduğu düşünülmektedir. Yerleşim alanlarında özellikle Demir, Roma ve Bizans çağı seramiklerinin yoğunlaştığı görülmektedir. Bununla birlikte Tunç çağına kadar uzanan seramik buluntularına da azda olsa rastlanmaktadır. Bu da Vezirköprü İlçesinin yerleşim tarihinin Tunç çağlarına kadar uzanan bir geçmişi olduğunu ortaya koymaktadır. Önümüzdeki yıl yapılacak yeni çalışmalarla birlikte antik kentin lokalizasyon sorunu ve yayılım alanının tespitinde önemli bir noktaya ulaşılması hedeflenmektedir.

Volume 12

Issue 2

A Tribute

to Assoc.

Prof. Dr.

İlknur

Mangir

Karagöz,

April

2020

\section{Kaynakça}

AKOK, Mahmut, “Samsun İli Havza İlçesi’nin Lerdüge Köyü’nde Bulunan Tümülüsler”, Belleten XII/48, (1948), s. 835-853.

ALKIM, U. Bahadır, "İslâhiye ve Samsun Bölgesinde 1971 Çalışmaları", Belleten XXXVI143, (1972), s. 422-426.

, "İslâhiye ve Samsun Bölgesinde 1972 Çalıșmaları", Belleten XXXVII147, (1973), s. 435-438.

, "Tilmen Höyük ve Samsun Bölgesi Çalışmaları 1971", Türk Arkeoloji Dergisi, 20-2, (1974a), s. 5-16.

(1974b), s. 553-556.

"Samsun Bölgesinde 1973 Çalışmaları", Belleten XXXVIII-151,

“Tilmen Höyük ve Samsun Bölgesi Çalıșmaları 1972”, Türk Arkeoloji

Dergisi 21-2, (1975a), s. 23-28.

"Samsun Bölgesi Çalışmaları (1973)", Türk Arkeoloji Dergisi 22-2,

(1975b), s. 5-12.

"Samsun Bölgesi Araştırmaları ve İkinci Dönem İkiztepe Kazısı", Belleten XL-160, (1976), s. 717-719.

"1977 Dönemi İkiztepe Kazısı ve Samsun Bölgesi Araştırmaları", Belleten XLII-167, (1978), s. 542-547.

ATASOY, Sümer - Muhsin ENDOĞRU - Şevket DÖNMEZ, "Samsun-Baruthane Tümülüsleri Kurtarma Kazısı”, Anadolu Araştırmaları Dergisi XVIII/2, (2005), s. 153-165. 
Neoklaudiopolis Antik Kenti ve Territoryumu 2018 Yüzey Araştırması ve Envanter Çalışmaları

BEKKER-NIELSEN, Tønnes, "New milestones from Neoklaudiopolis", Epigraphica Anatolica 43, (2010), s. 87-91.

,- Christian HÖGEL, "Three Epitaphs from the Vezirköprü Region", Epigraphica Anatolica 45, (2012), s. 153-160.

, "Neapolis-Neoklaudiopolis: A Roman City in Northern Anatolia", (Ed. Ünsal Yalçın), Anatolian Metal VI, 203-213, Bochum 2013a.

"Neoklaudiopolis'in Araştırma Tarihi Üzerine Notlar (Vezirköprü, Samsun İli)", Höyük 6, (2013b), s. 39-58.

, Rainer M. CZICHON-Christian HÖGEL-Bünyamin KIVRAK- Jesper M. MADSEN-Vera SAUER-Soren L. SORENSEN-Kristina WINTHER-JACOBSEN, Neoklaudioplis Antik Kenti (Vezirköprü-Samsun) Tarihsel ve Arkeolojik Rehber (Çev. Özge Acar), İstanbul 2015a.

,- Rainer M. CZICHON, "Ancient Roads and Bridges of the Vezirköprü District", $\underline{K}$. Landscape Dynamics and Settlement Patterns in Northern Anatolia during the Roman Byzantine Period (Eds. K. Winther-Jacobsen, L. Summerer): 295-307. Stuttgart 2015 b.

CZICHON, Rainer M., "Oymaagac-Vezirköprü-Survey Report 2005, in: M.H. Gates/B. Y1ldirım, Archaeology in Turkey", American Journal of Archaeology 111,2, (2007), s. 300 .

, “Oymaağaç- Vezirköprü Yüzey Araştırması 2006”, 25. Araştırma Sonuçları Toplantısı 1, (2008), s. 187-196.

,-Jörg KLINGER, "Karadeniz'deki Hititler: Nerik-Zalpa", Aktüel Arkeoloji Dergisi, Kasim 8, (2010), s. 58-65.

,- Jörg KLINGER - Peter BREUER - Jacop EERBEEK - Sherry FOX Elena MARINOVA-WOLFF - Henning MARQUARDT - Harald von der OSTENWOLDENBURG - Silvio REICHMUTH - Simone RIEHL - Theodor JOHANNSEN, "Archäologische Forschungen am Oymaağaç Höyük/Nerik (?) in den Jahren 20072010", Mitteilungen der Deutschen Orient-Gesellschaft 143, (2011), s. 169-250.

DENGATE, J. Andrew, "A Site Survey along the South Shore of Black Sea”, The Proceedings of the Xth International Congress of Classical Archaeology, Ankara-İzmir 2330/IX/1973, 1, (1978), s. 245-258.

FRENCH, David, Roman Roads and Milestones of Asia Minor, Fasc. 2.1: An Interim Catalogue of Milestones (British Institute of Archaeology at Ankara Monograph, 9; British Archaeological reports, International Series, 392/I), Oxford 1988.

HALİFEOĞLU, F. Meral - Halide SERT - Süheyla YILMAZ, “Tarihi Kurt Köprüsü (Mihraplı Köprü, Vezirköprü) Restorasyonu Proje Ve Uygulama Çalışmaları”, METU JFA /2, (2013) s. 81-104.

KAHL, Gerhard- Eckart OLSHAUSEN, "Bericht über die Epigraphische und Numismatische Landesaufname im Samsun İli 1990", Araştırma Sonuçları Toplantısı, (1991), s. 611616.

KIZILTAN, Zeynep, "Samsun Bölgesi Yüzey Araştırmaları”, Belleten LVI-215, (1992), 213241.

Volume 12

Issue 2

A Tribute to

Assoc. Prof.

Dr. İlknur

Mangir

Karagöz,

April

2020 
ÖZSAİT, Mehmet, "2002 Yılı Samsun-Amasya Yüzey Araştırmalarının İlk Sonuçları”, 21. Araştırma Sonuçları Toplantısı 2, (2003), s. 273-284.

TEMÜR, Akın, "Ein Ohrring mit Sphingenmotiv aus Vezirköprü-Samsun (Nordtürkei)", Mitteilungen der Deutschen Orient Gesellschaft 148, (2016), s. 165-177.

ÜNAN, Serdar, "Samsun/Dondortepe (Hac1 İsmail) Tümülüsü”, MASROP E-Dergi 4, (2009), s. $1-28$.

"Tunç Çă̆g'ndan Roma Dönemi'ne Amisos ve Çevresinde Yer Alan Mezar Tipleri ve Ölü Gömme Adetleri Üzerine Genel Bir Değerlendirme”, Güneş Karadeniz'den Doğar Sümer Atasoy'a Armağan Yazılar, (Ed. Şevket Dönmez). Ankara 2013, s. 387-414.

Volume 12

Issue 2

A Tribute

to Assoc.

Prof. Dr.

İlknur

Mangir

Karagöz,

April

2020 
Neoklaudiopolis Antik Kenti ve Territoryumu 2018 Yüzey Araştırması ve Envanter Çalışmaları

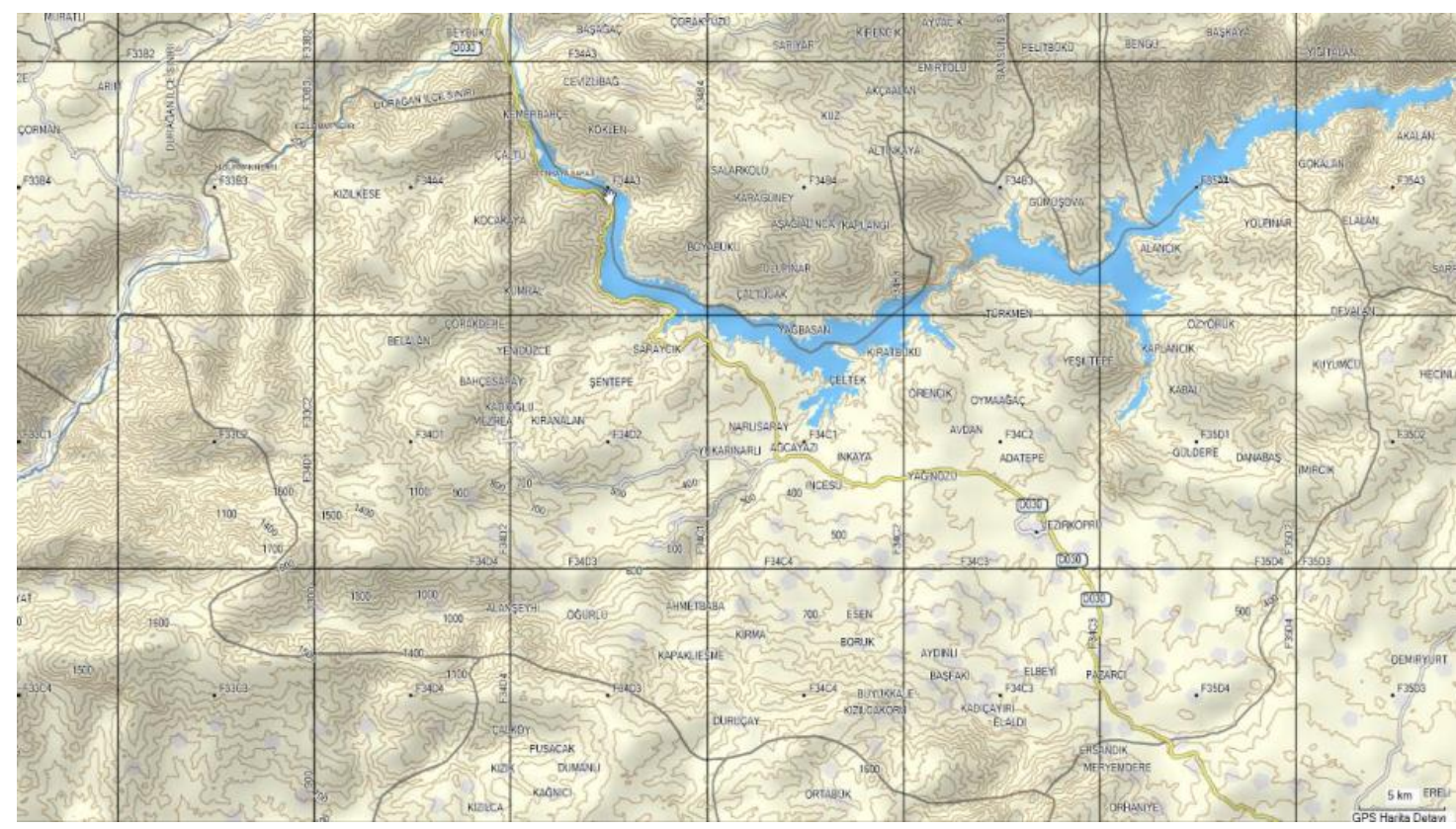

Harita 1: Vezirköprü Haritası

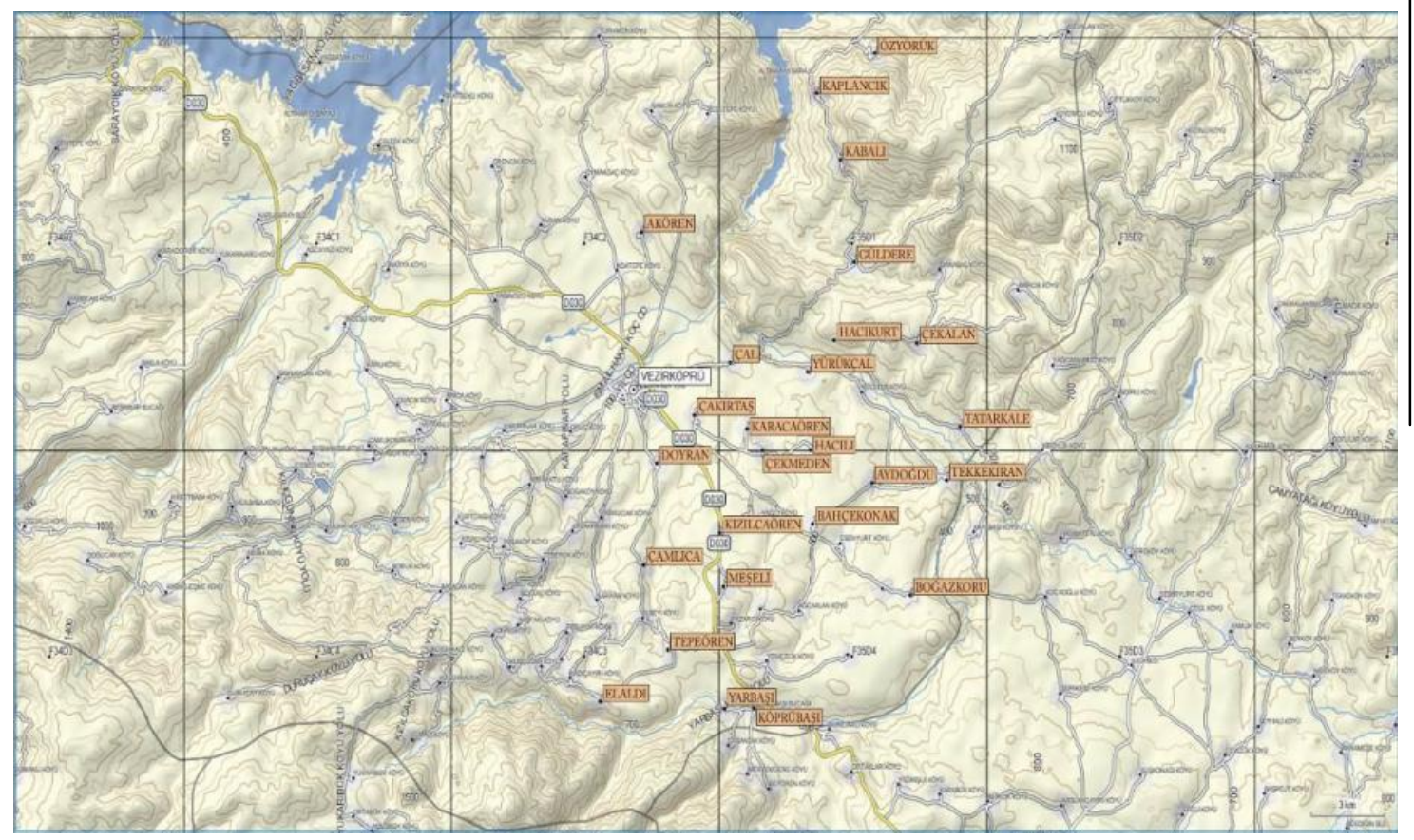

Volume 12

Issue 2

A Tribute to

Assoc. Prof.

Dr. İlknur

Mangir

Karagöz,

April

2020

Harita 2: 2018 Sezonunda Çalışılan Alanların Haritası 


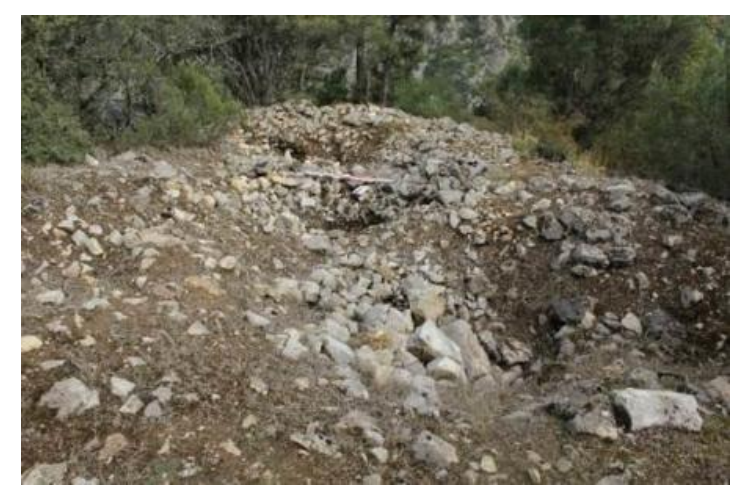

Res. 1: Kale, Gavurevi Mevkii (Çalköy)

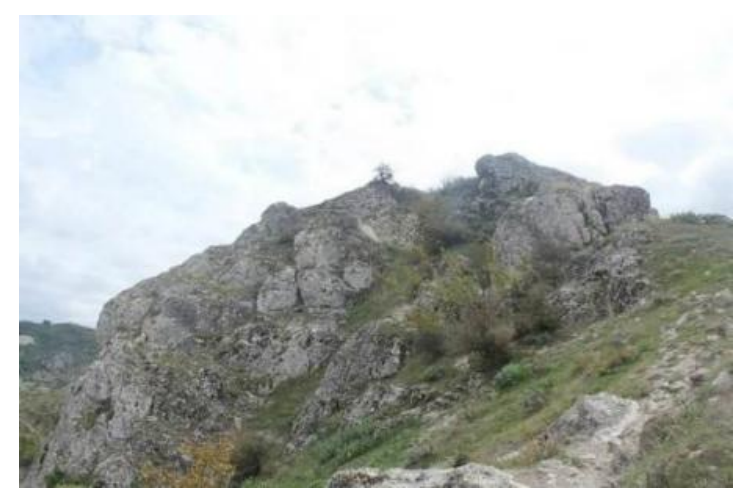

Res. 2: Kale, Kale Mevkii (Tekkekıran)

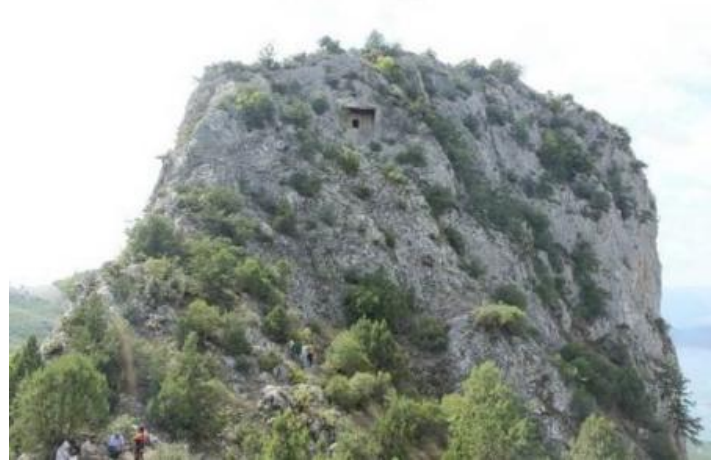

Res. 3: Kale (Özyörük) 


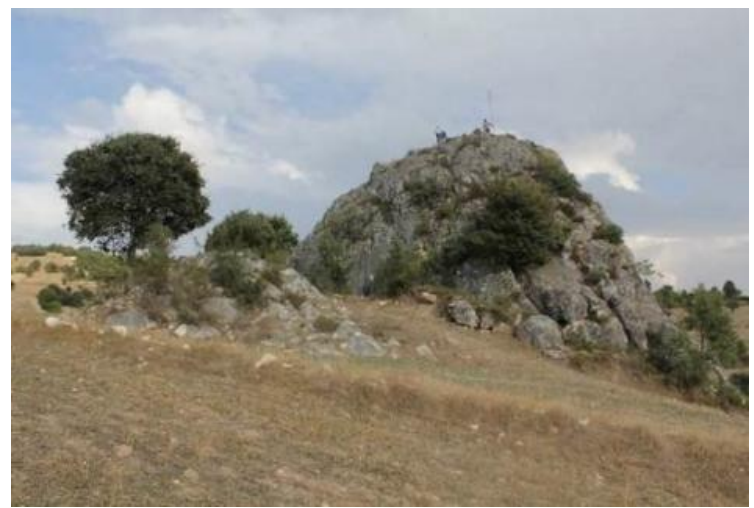

Res. 4: Gözetleme Kulesi, Köyaltı Mevkii (Çekalan)

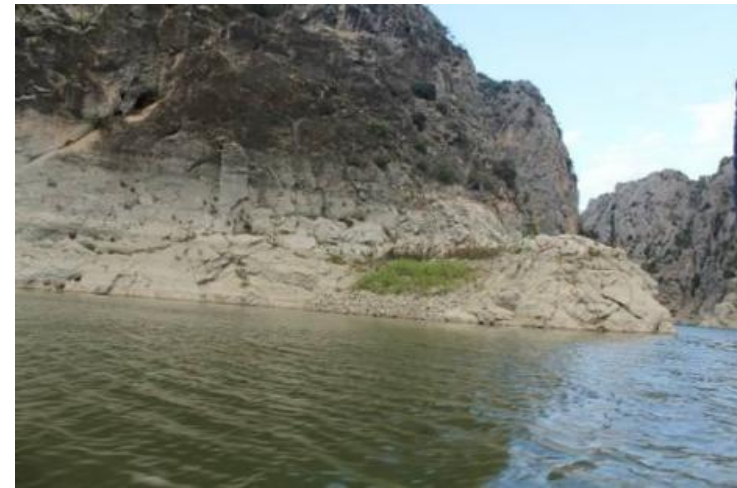

Res. 5: Gözetleme Kulesi, Kanyon-Gavuryolu Mevkii (Kaplancık)

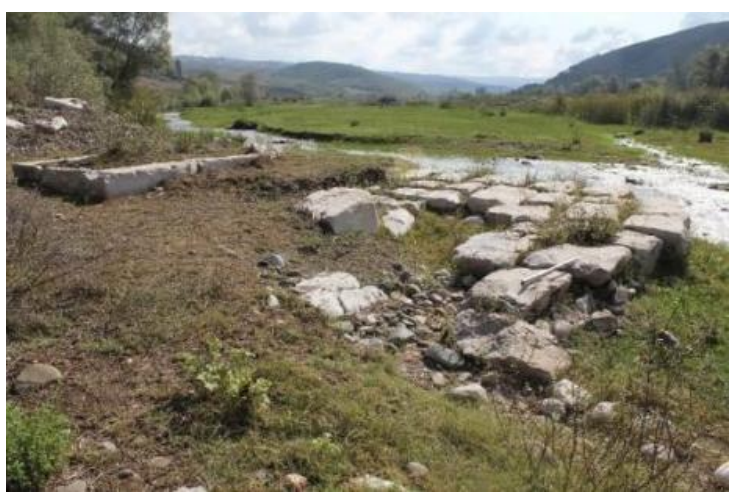

Res. 6: Roma Köprüsü (Yürükçal) 


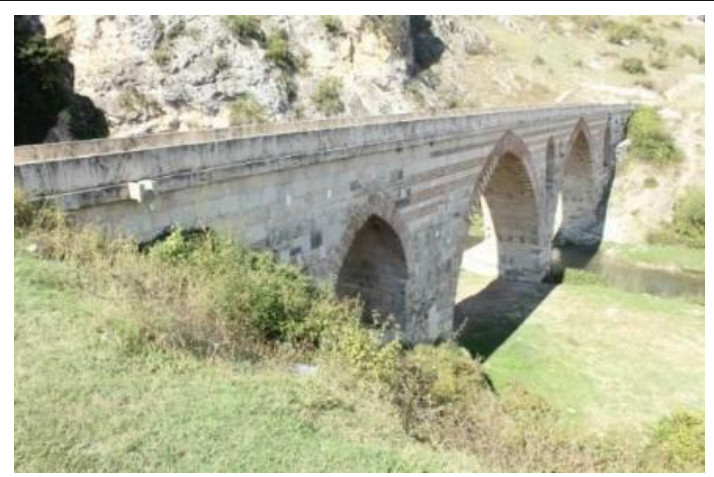

Res. 7: Kurt Köprü (Tekkekıran)

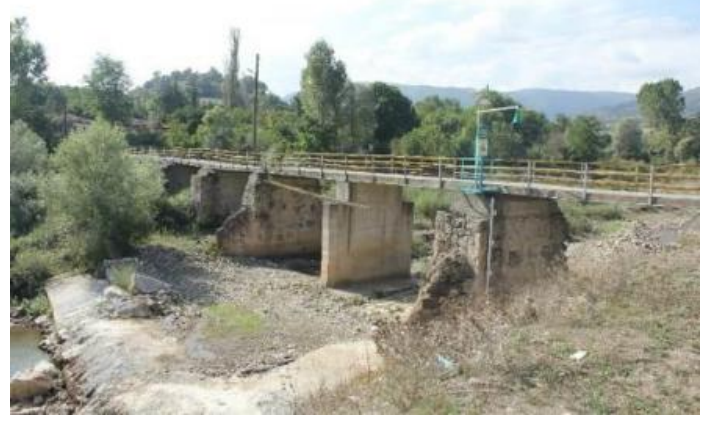

Res. 8: Köprü (Köprübaşı)

Volume 12

Issue 2

A Tribute

to Assoc.

Prof. Dr.

İlknur

Mangir

Karagöz,

April

2020

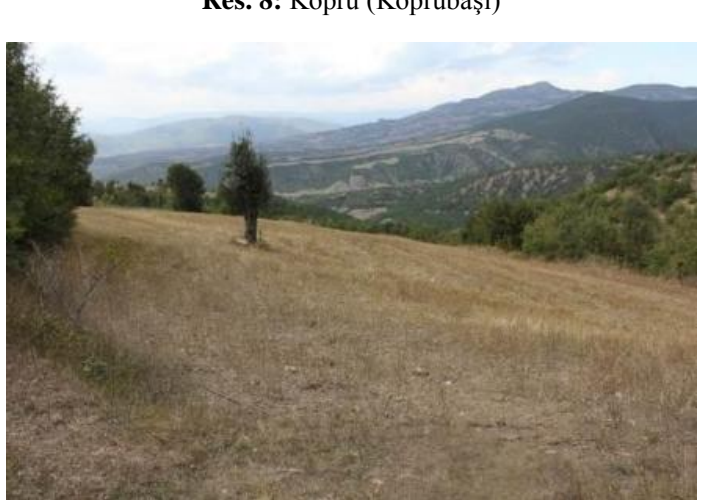

Res. 9: Yamaç Yerleşimi, Kocakarıpınarı Mevkii (Çekalan)

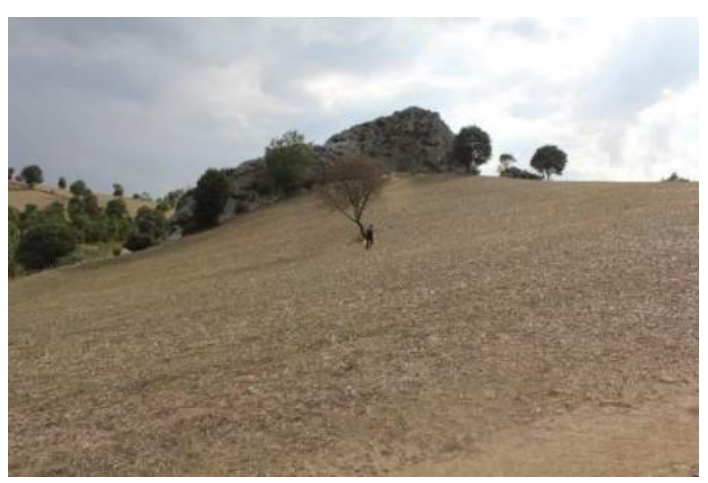

Res. 10: Yamaç Yerleşimi, Köyaltı Mevkii (Çekalan) 


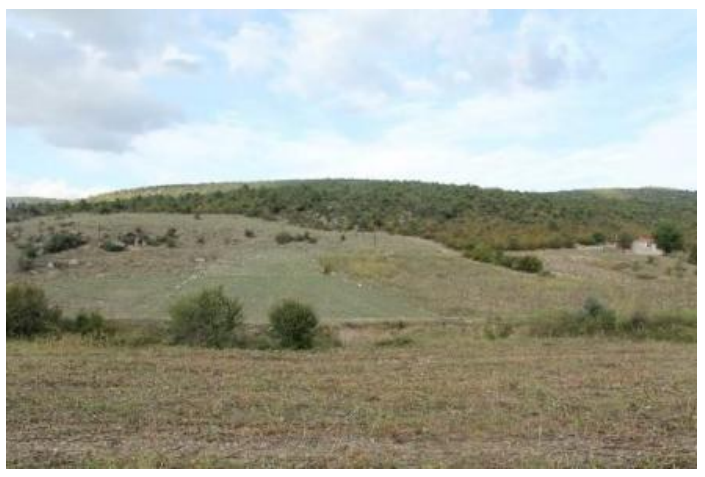

Res. 11: Yamaç Yerleşimi, Baykuşkaya Mevkii (Çalköy)

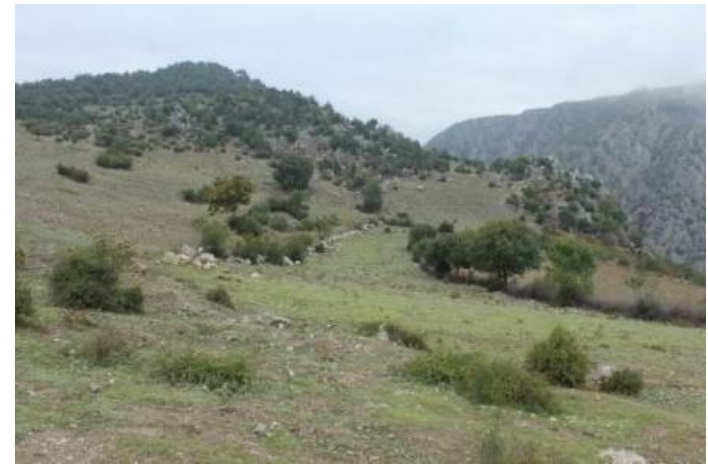

Res. 12: Yamaç Yerleşimi, Gavurevi Mevkii (Çalköy)

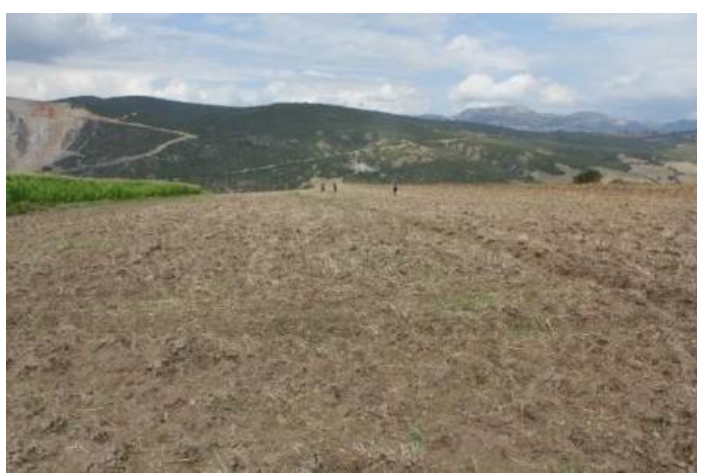

Res. 13: Ortaçağ Yerleşimi, Bidene Mevkii (Yürükçal)

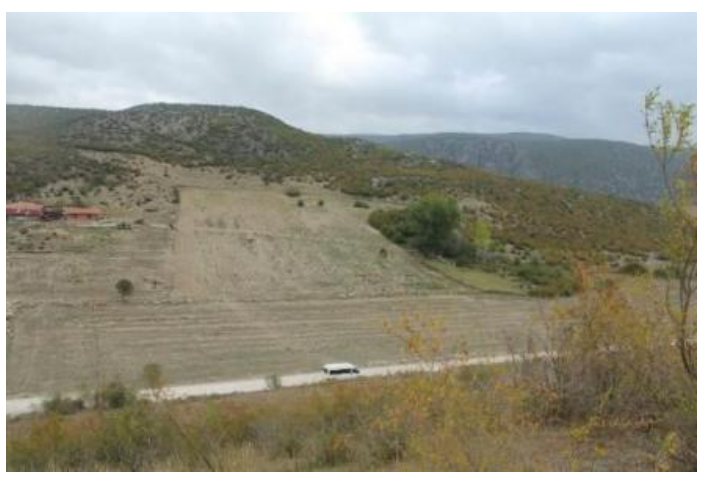

Res. 14: Yamaç Yerleşimi, Tevekleşme Mevkii (Akören)

Issue 2

A Tribute to

Assoc. Prof.

Dr. Illknur

Mangir

Karagöz,

April

2020 


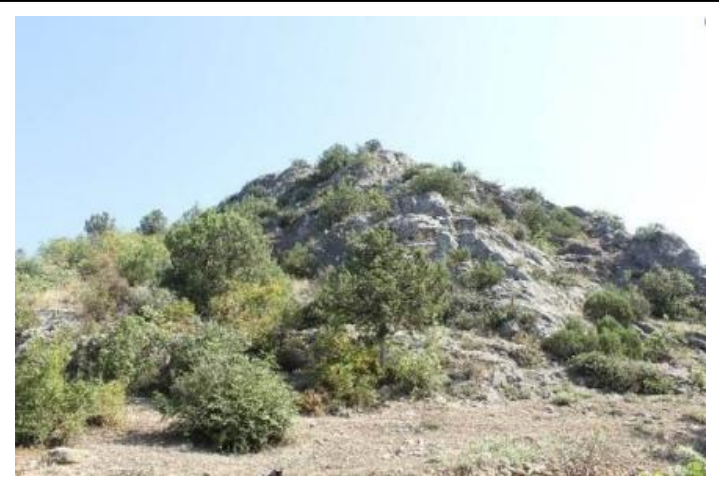

Res. 15: Yamaç Yerleşimi, Kilisekaya Mevkii (Hacıkurt)

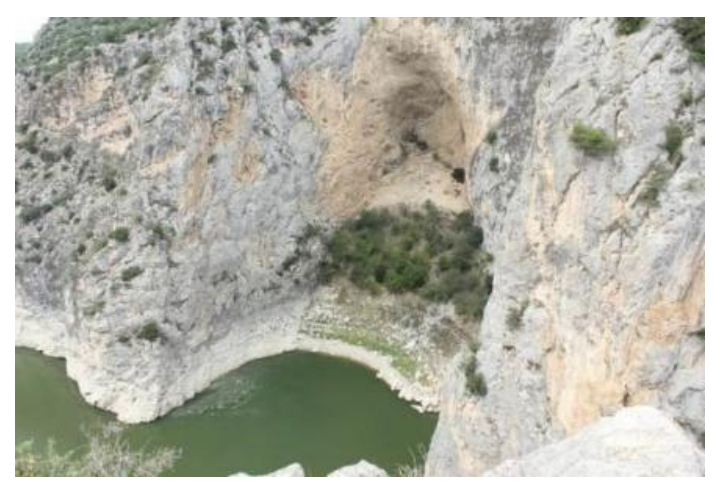

Res. 16: Kaplancık Yerleşimi, Bedesten Mevkii (Kaplancık)

Volume 12

Issue 2

A Tribute

to Assoc.

Prof. Dr.

İlknur

Mangir

Karagöz,

April

2020

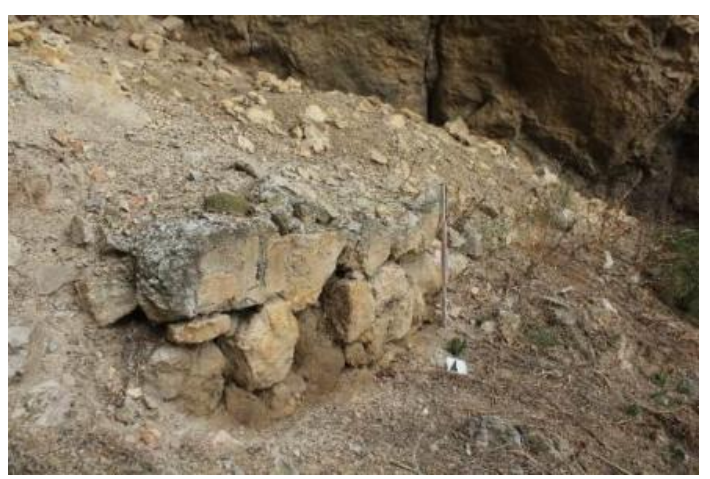

Res. 17: Kaplancık Yerleşimi, Kanyon Bedesten Mevkii, (Kaplancık)

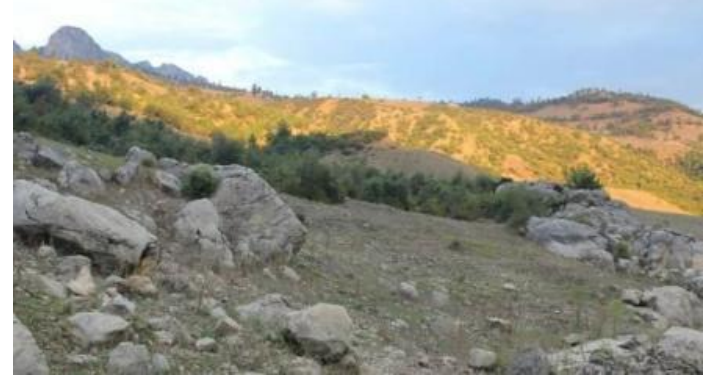

Res. 18: Yamaç Yerleşimi, Harmankaya Mevkii (Kaplancık)

\section{History Studies}




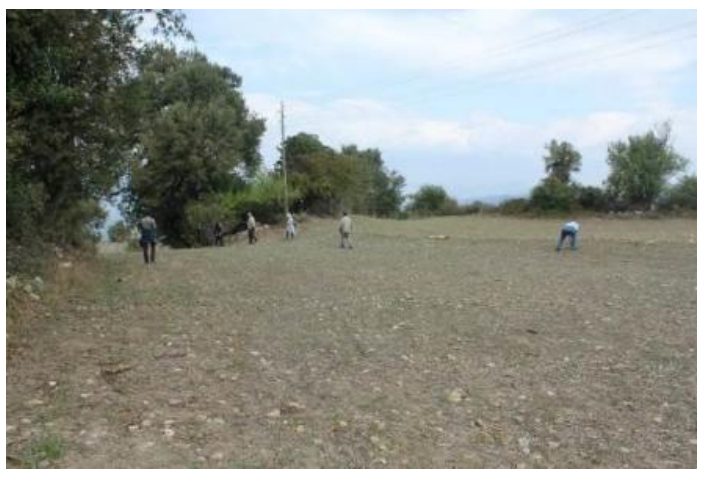

Res. 19: Yamaç Yerleşimi, Oluklu Mevkii (Kabalı)

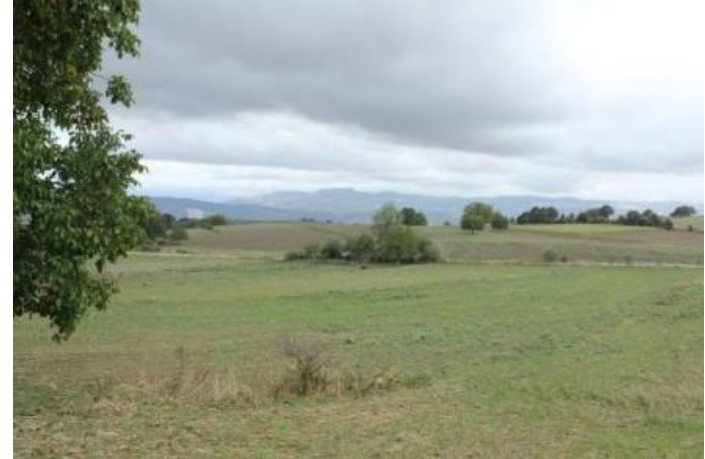

Res. 20: Yamaç Yerleşimi Ömer (Taşlık) Mevkii (Meşeli)

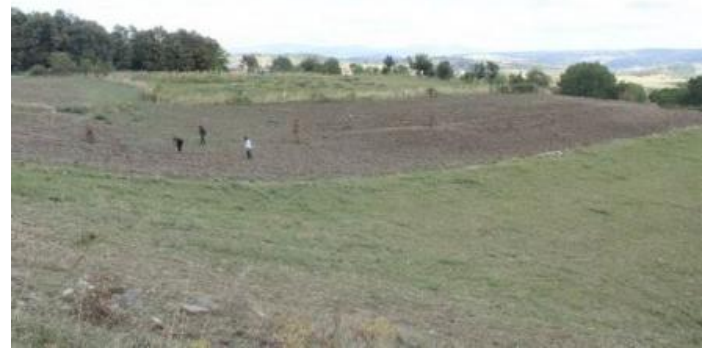

Dr. İlknur Mangir Karagöz, April 2020

Res. 21: Yamaç Yerleşimi, Mezarlık Mevkii (Tepeören)

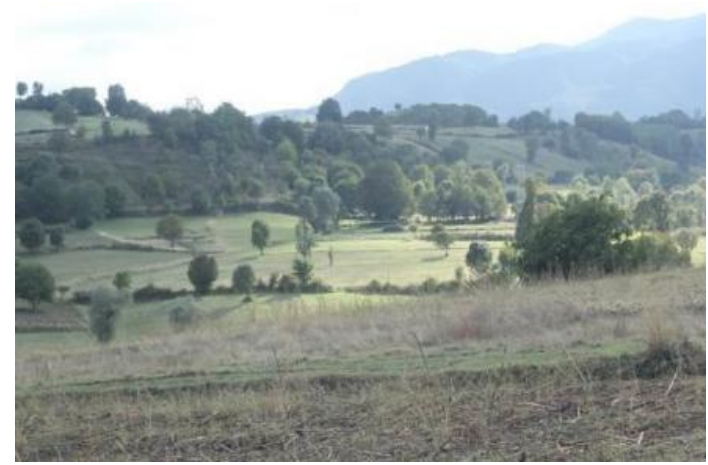

Res. 22: Yamaç Yerleşimi, Taşlıpınar (Ağırtarla) Mevkii (Tepeören)

\section{History Studies}




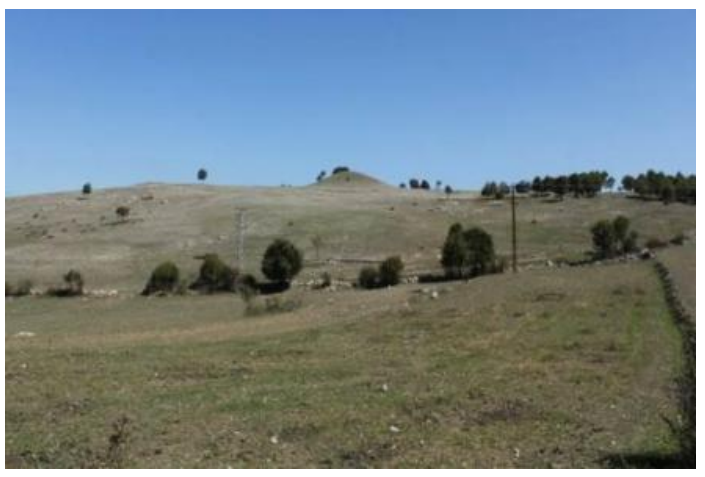

Res. 23: Maltepe Yamaç Yerleşimi (Boğazkoru)

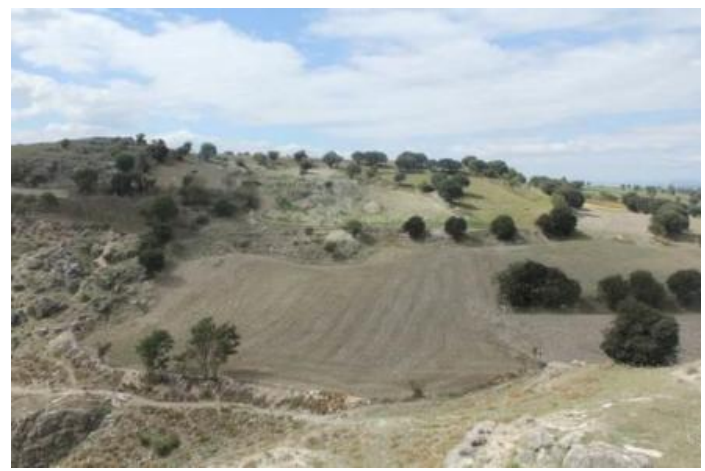

Res. 24: Yamaç Yerleşimi, Kale Mevkii (Tekkekıran)

Volume 12

Issue 2

A Tribute

to Assoc.

Prof. Dr.

İlknur

Mangir

Karagöz,

April

2020

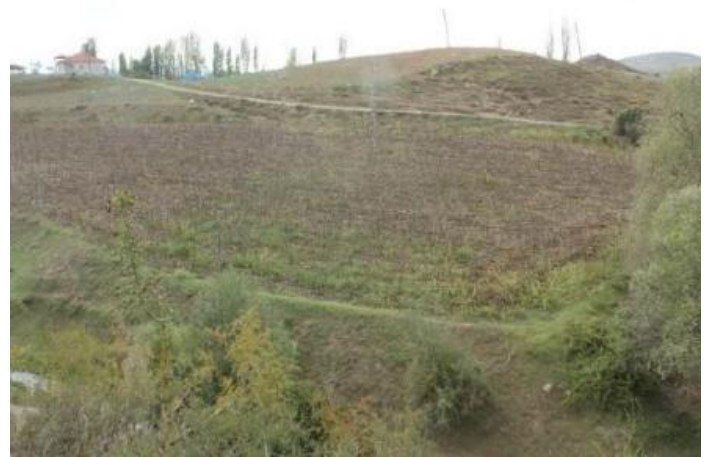

Res. 25: Camii Tepesi Höyügü, Kayalı Mevkii (Çalköy)

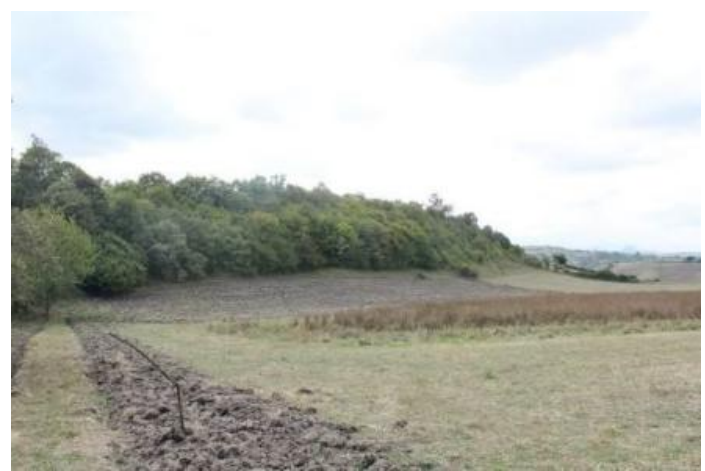

Res. 26: Kaledoruğu Höyüğü, Kaledoruk Mevkii (Yarbaşı)

\section{History Studies}


Neoklaudiopolis Antik Kenti ve Territoryumu 2018 Yüzey Araştırması ve Envanter Çalışmaları

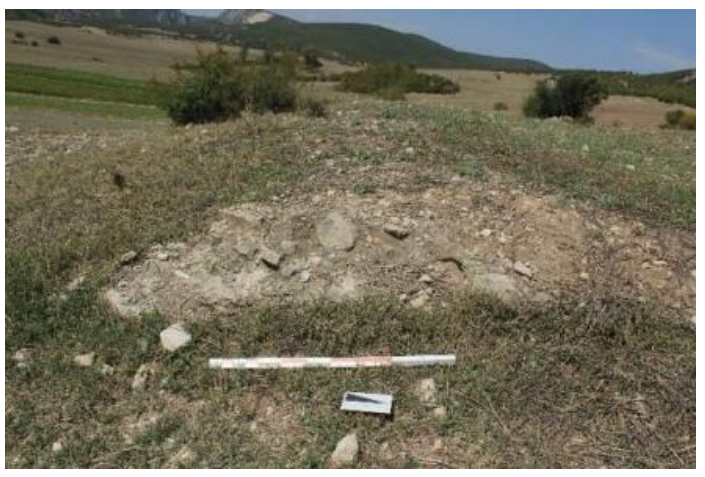

Res. 27: Yapı Kalıntısı, Hozan Mevkii (Hacıkurt)

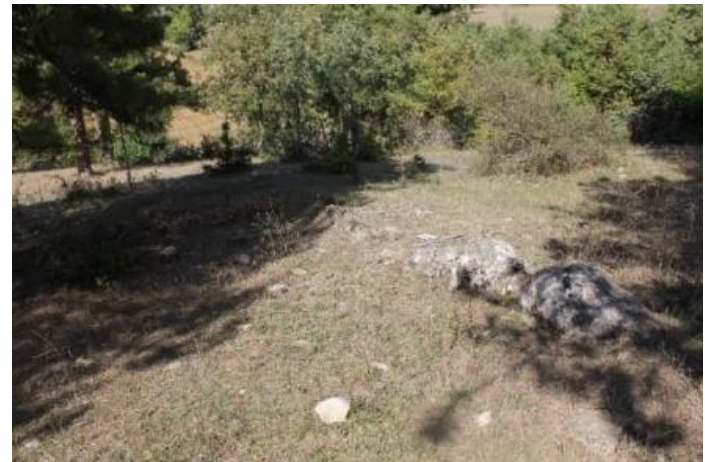

Res. 28: Duvar Kalıntısı, Kocakarıpınarı Mevkii (Çekalan)

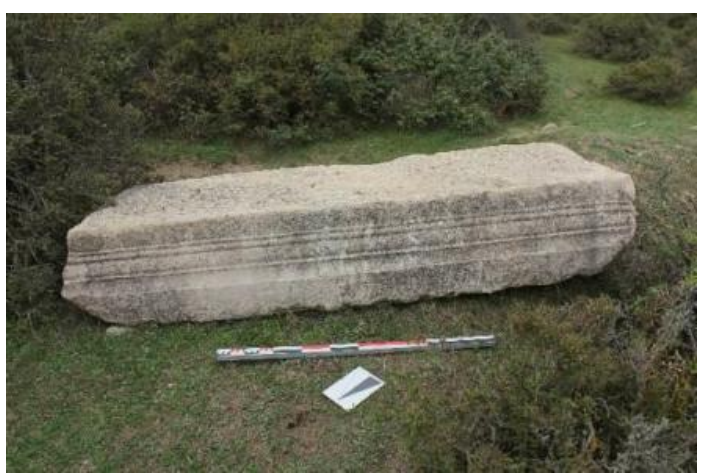

Volume 12

Issue 2

A Tribute to

Assoc. Prof.

Dr. Illknur

Mangir

Karagöz

April

2020

Res. 29: Arşitrav Bloğu, Ötegece Mevkii (Çamlıca)

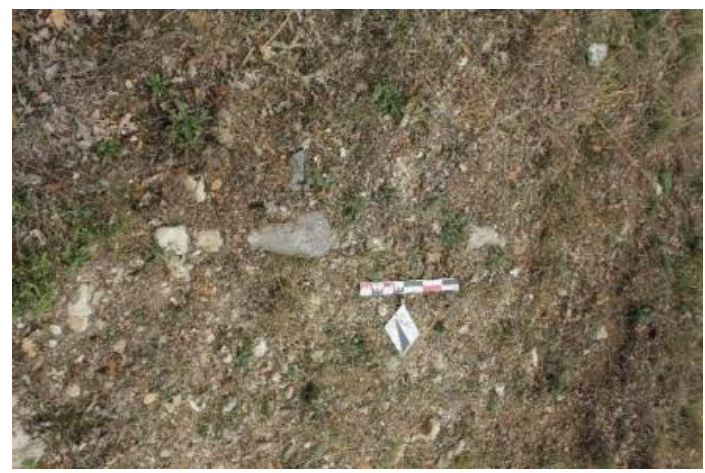

Res. 30: Duvar Kalıntısı，Eşebaba Mevkii (Köprübaşı)

\section{History Studies}




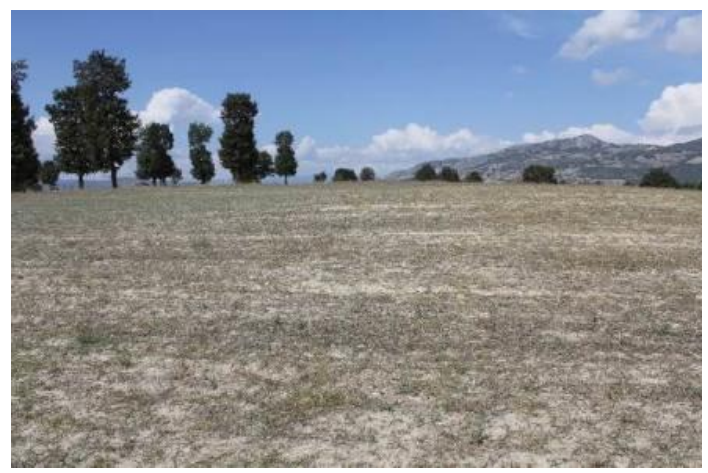

Res. 31: Derenöz Tümülüsü I, Derenöz Mevkii (Çekalan)

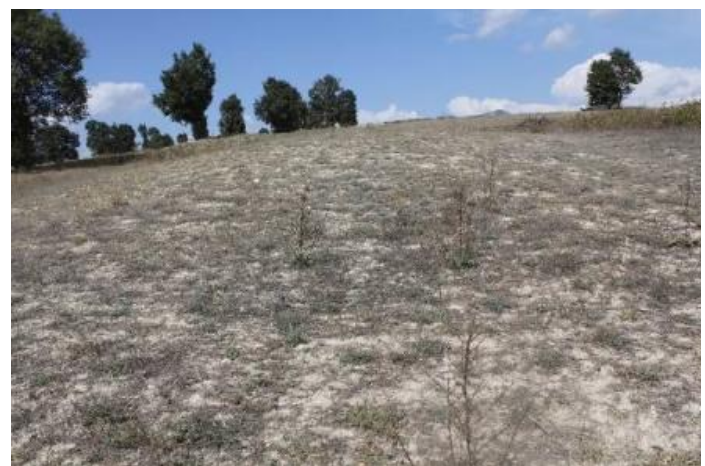

Res. 32: Derenöz Tümülüsü II, Derenöz Mevkii (Çekalan)

Volume 12

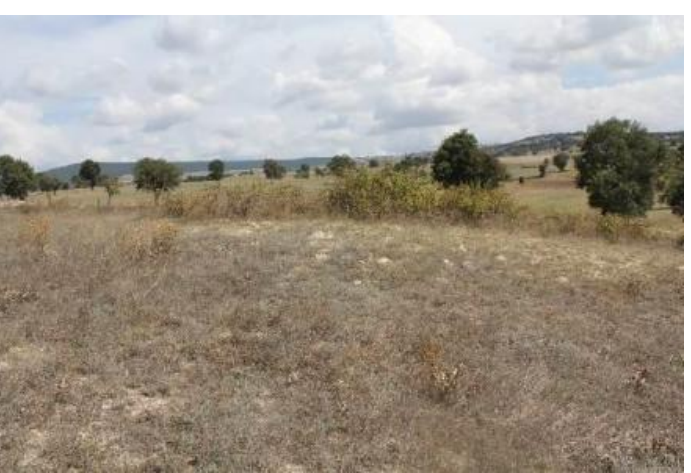

Res. 33: Derenöz Tümülüsü III, Derenöz Mevkii (Çekalan)

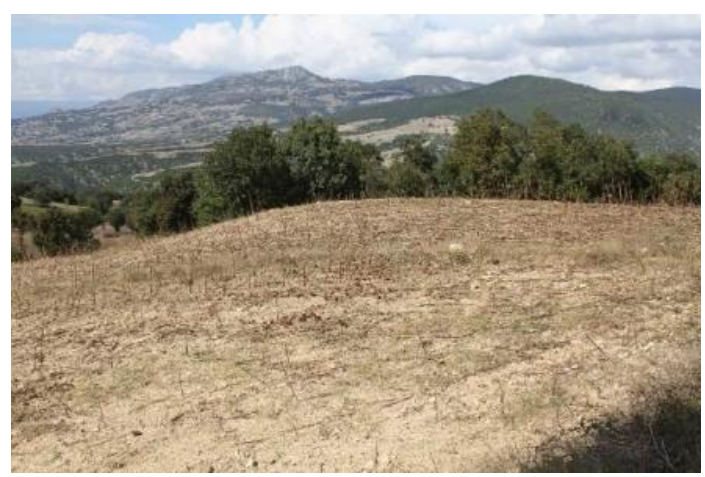

Res. 34: Çekalan Tümülüs I, Armutarası Mevkii (Çekalan)

\section{History Studies}


Neoklaudiopolis Antik Kenti ve Territoryumu 2018 Yüzey Araştırması ve Envanter Çalışmaları

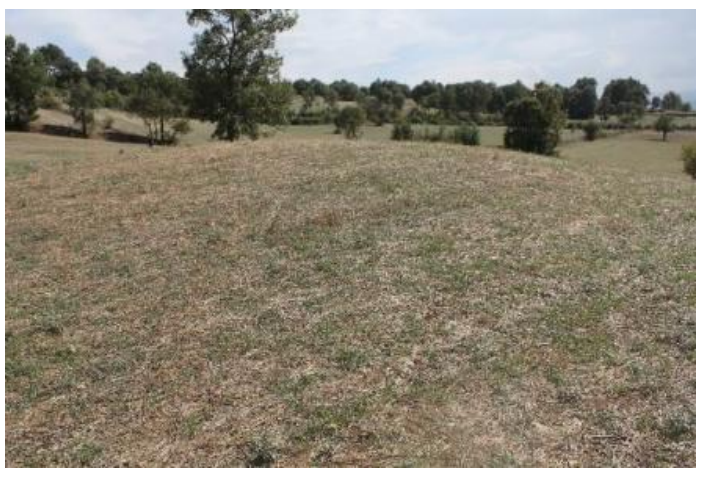

Res. 35: Çekalan Tümülüs II, Armutarası Mevkii (Çekalan)

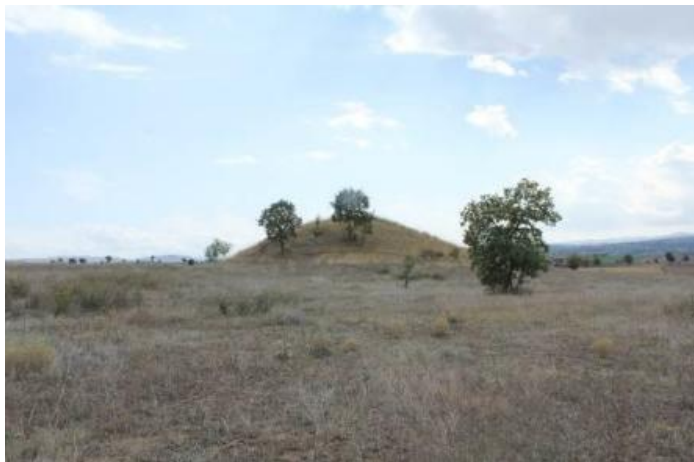

Res. 36: Kuştepe Tümülüsü, Kuştepe Mevkii (Yürükçal)

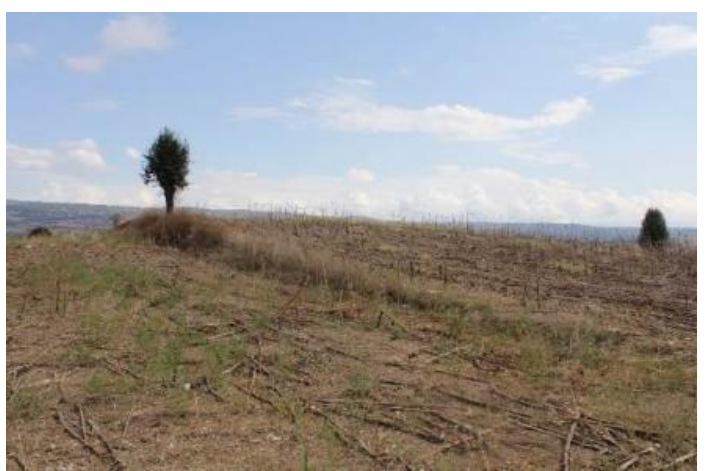

Issue 2

A Tribute to

Assoc. Prof.

Dr. İlknur

Mangir

Karagöz,

April

2020

Res. 37: İkiztepe I Tümülüsü (Bahçekonak)

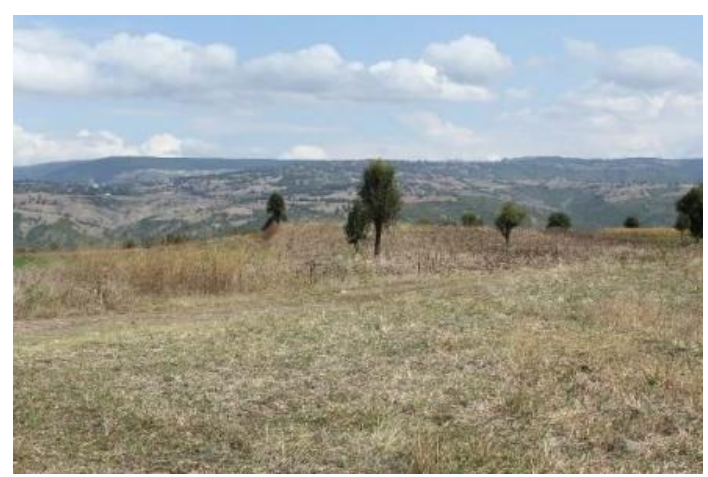

Res. 38: İkiztepe II Tümülüsü (Bahçekonak) 


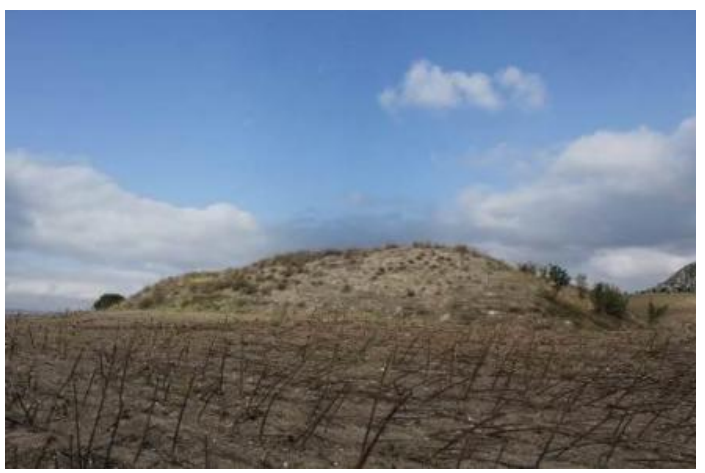

Res. 39: Çalköy Tümülüsü (Çalköy)

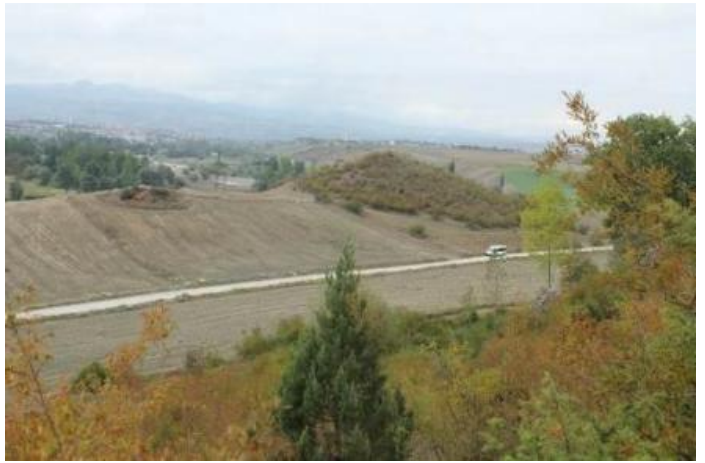

Res. 40: Dökmetepe Tümülüsü (Akören)

Volume 12

Issue 2

A Tribute

to Assoc.

Prof. Dr.

İlknur

Mangir

Karagöz,

April

2020

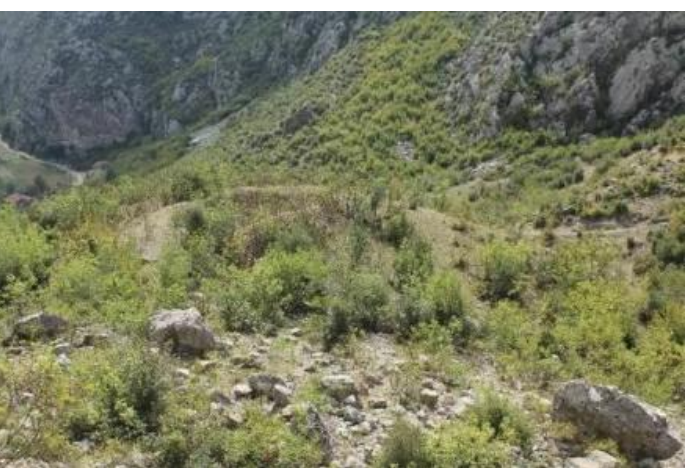

Res. 41: Tümülüs, Kabaktepe Mevkii (Akören)

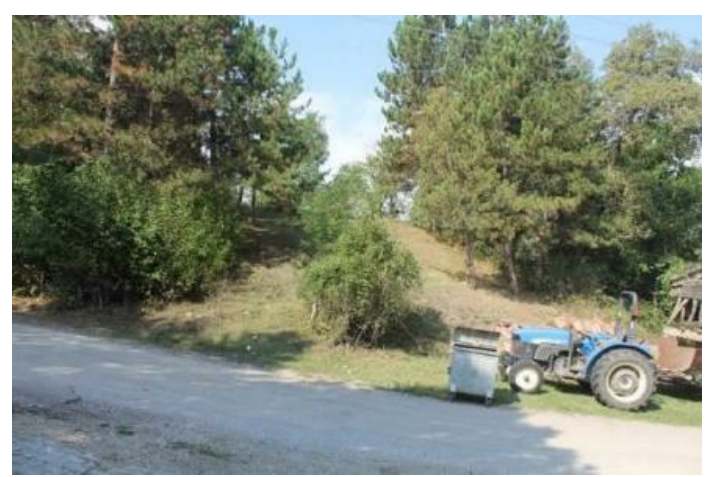

Res. 42: Tümülüs, Camitepe Mevkii (Köprübaşı)

\section{History Studies}




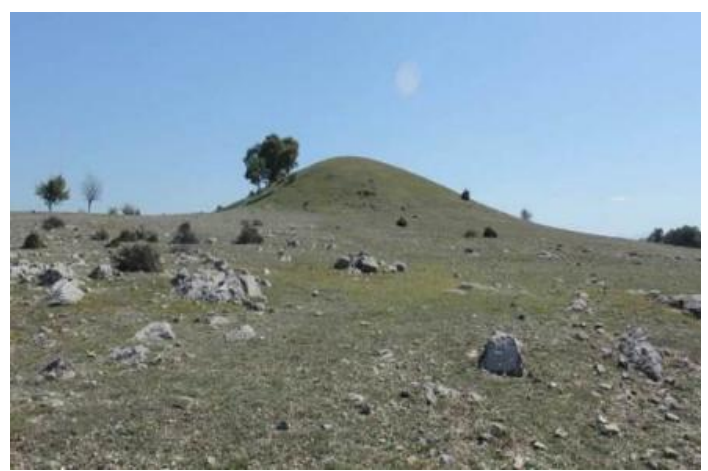

Res. 43: Maltepe Tümülüsü, Maltepe Mevkii (Boğazkoru)

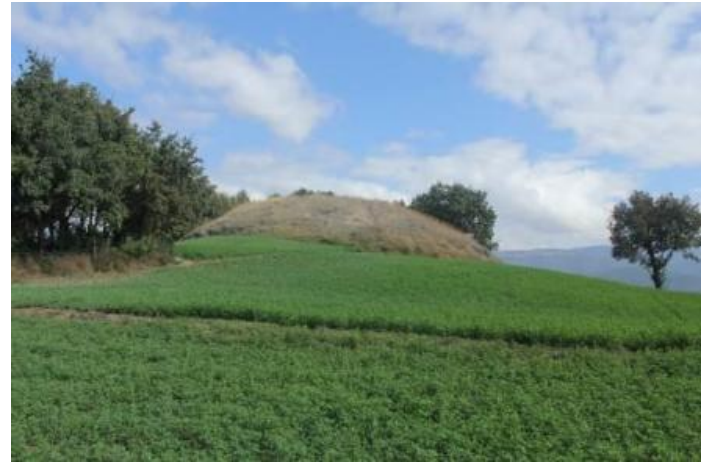

Res. 44: Tümülüs (Tekkekıran)

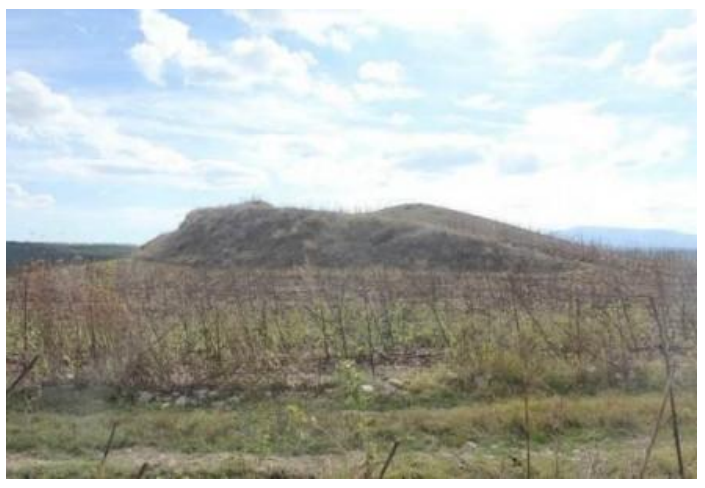

Volume 12

Issue 2

A Tribute to

Assoc. Prof.

Dr. İlknur

Mangir

Karagöz,

April

2020

Res. 45: Tümülüs, Aşağıtepe Mevkii (Tekkekıran)

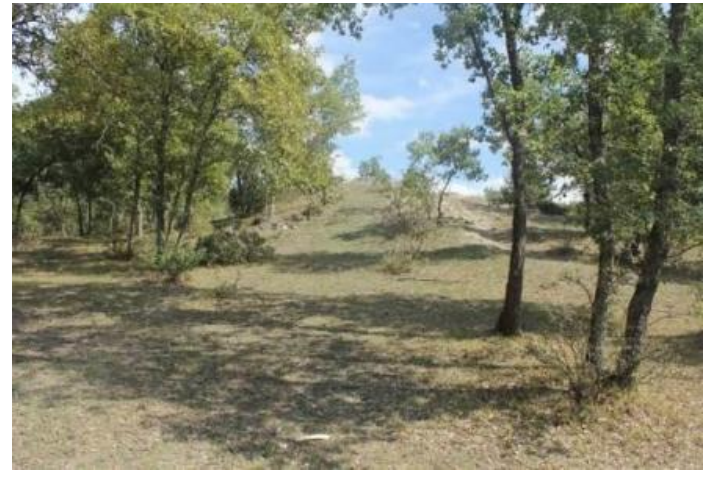

Res. 46: Tümülüs, Arpalık Mevkii (Aydoğdu)

\section{History Studies}




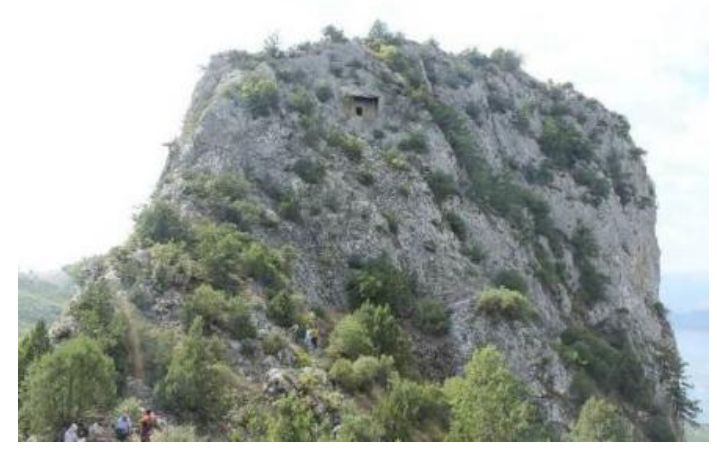

Res.47: Kaya Mezarı (Özyörük)

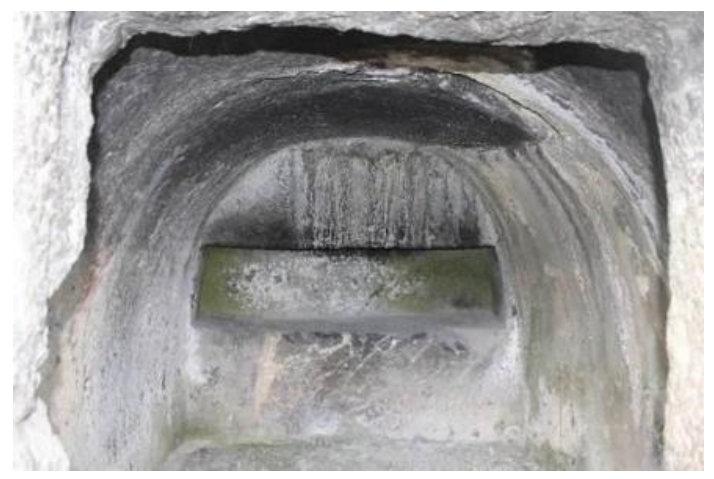

Res. 48: Kaya Mezarı Odası (Özyörük)

Volume 12

Issue 2

A Tribute

to Assoc.

Prof. Dr.

İlknur

Mangir

Karagöz,

April

2020

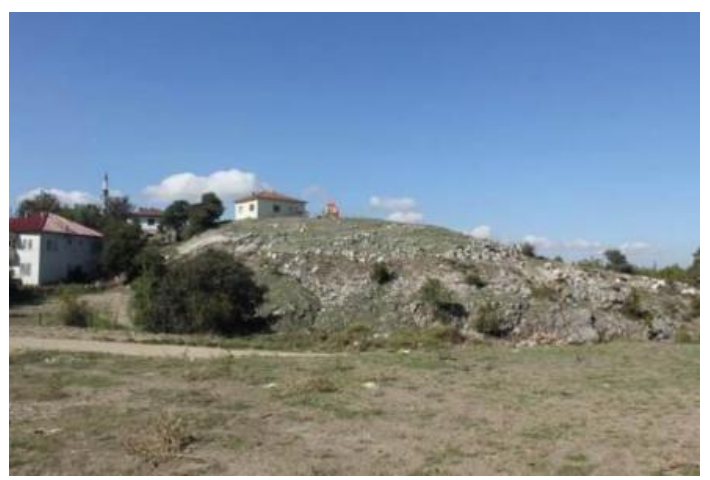

Res. 49: Kaya Oygu Mezarları, Köy Konağı Mevkii (Boğazkoru)

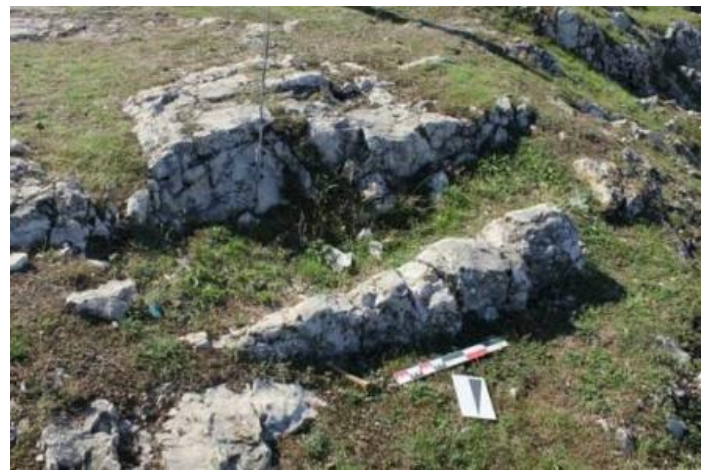

Res. 50: 4 Nolu Kaya Oygu Mezarı (Boğazkoru)

\section{History Studies}


Neoklaudiopolis Antik Kenti ve Territoryumu 2018 Yüzey Araştırması ve Envanter Çalışmaları

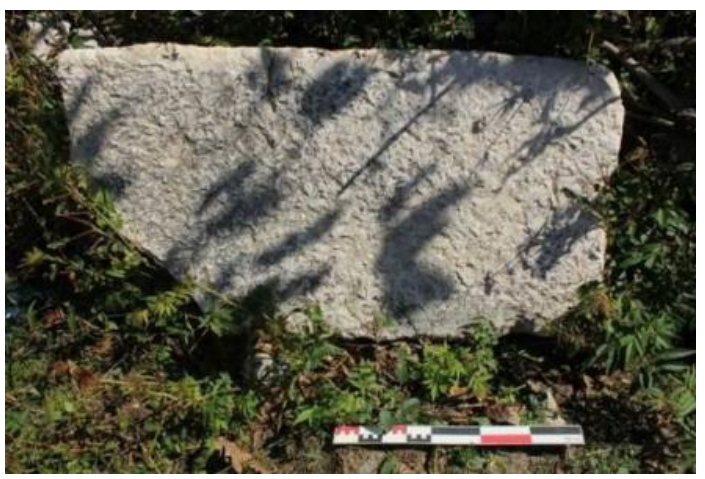

Res. 51: Mezar Kapağı, Köy Konağı Mevkii (Boğazkoru)

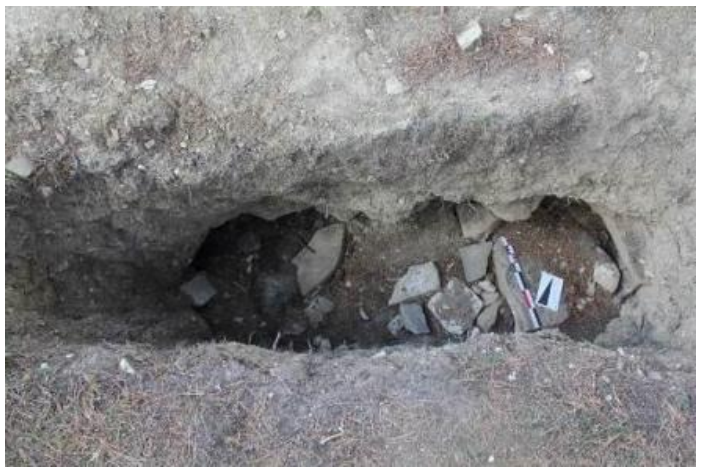

Res. 52: 1 Nolu Sandık Mezar, Kocakarıpınarı Mevkii (Çekalan)

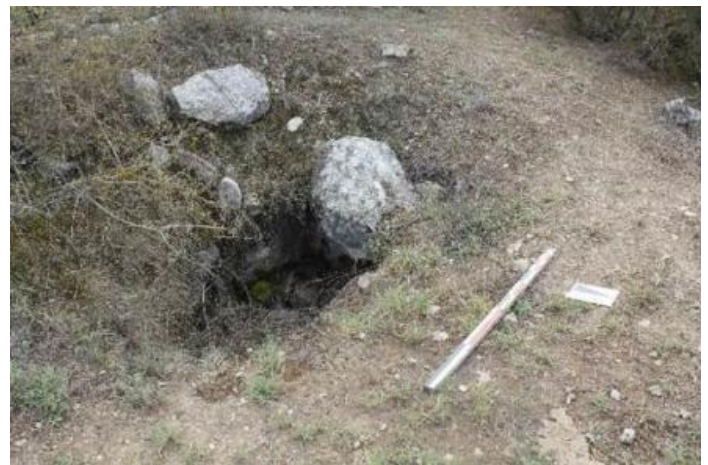

Volume 12

Issue 2

A Tribute to

Assoc. Prof.

Dr. İlknur

Mangir

Karagöz,

April

2020

Res. 53: Taş Sandık Mezar, Baykuşkaya Mevkii (Çalköy)

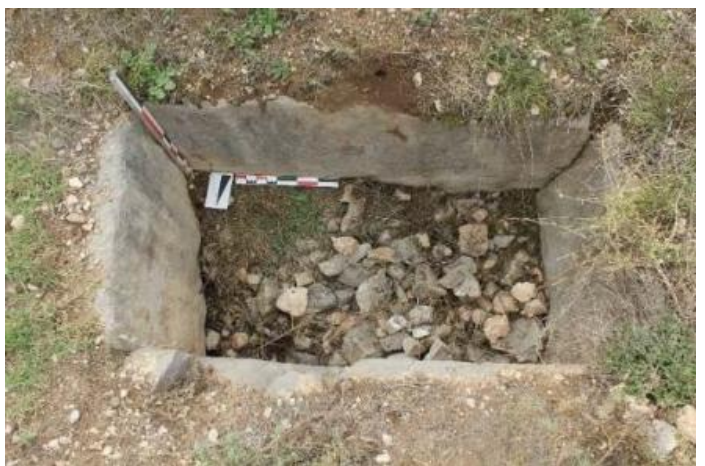

Res. 54: Taş Sandık Mezar, Tevekleşme Mevkii (Akören)

\section{History Studies}




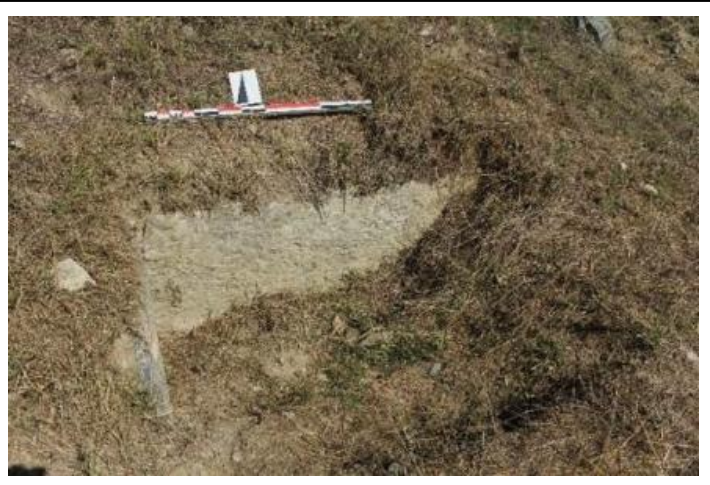

Res. 55: Taş Sandık Mezar, Hozan Mevkii (Hacıkurt)

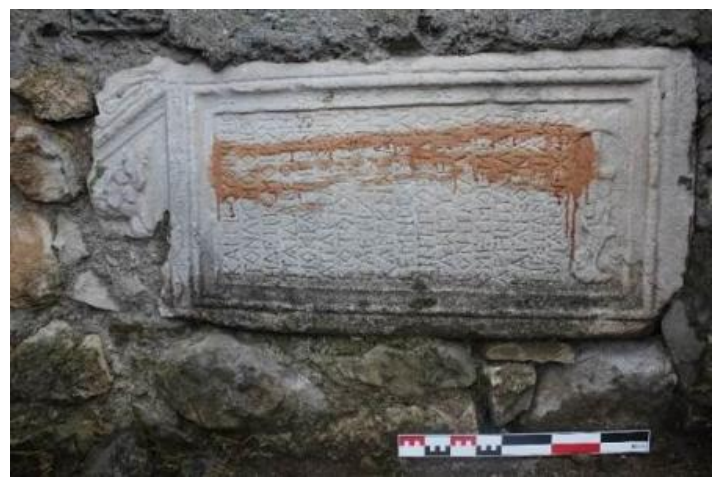

Res. 56: Mezar Steli (Çalköy)

Volume 12

Issue 2

A Tribute

to Assoc.

Prof. Dr.

İlknur

Mangir

Karagöz,

April

2020
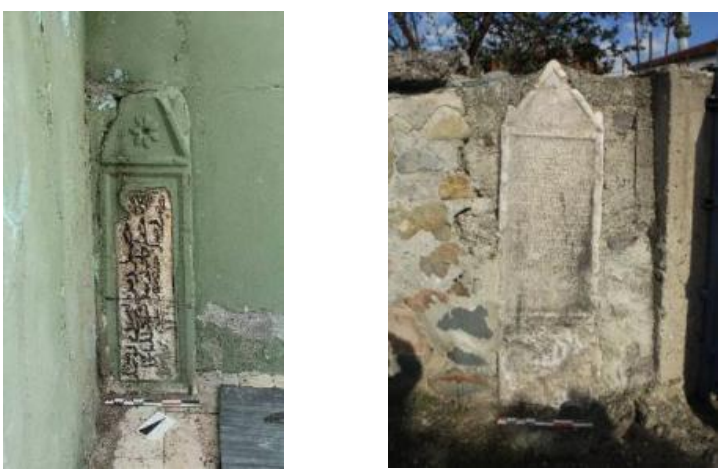

Res. 57: Mezar Steli (Kızılcaören) Res. 58: Mezar steli (Tepeören)

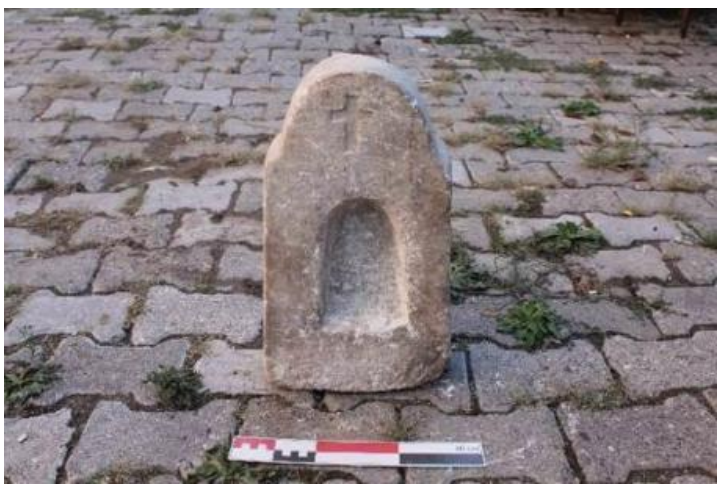

Res. 59: Mezar steli (Tepeören)

\section{History Studies}



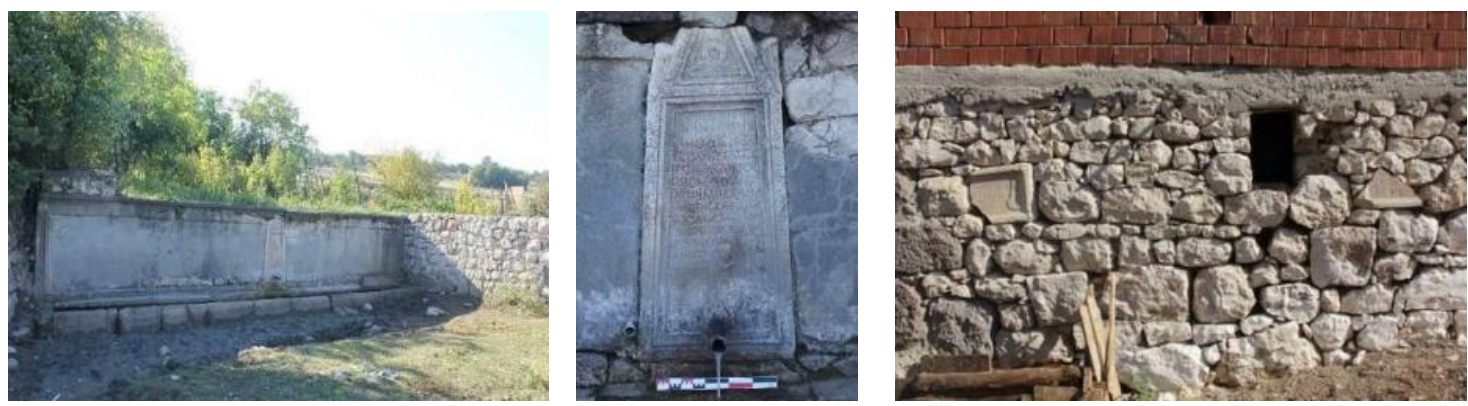

Res. 60: Mezar Steli (Boğazkoru)

Res. 61: Mezar Steli (Boğazkoru)

Res. 62: Stel parçaları (Boğazkoru)

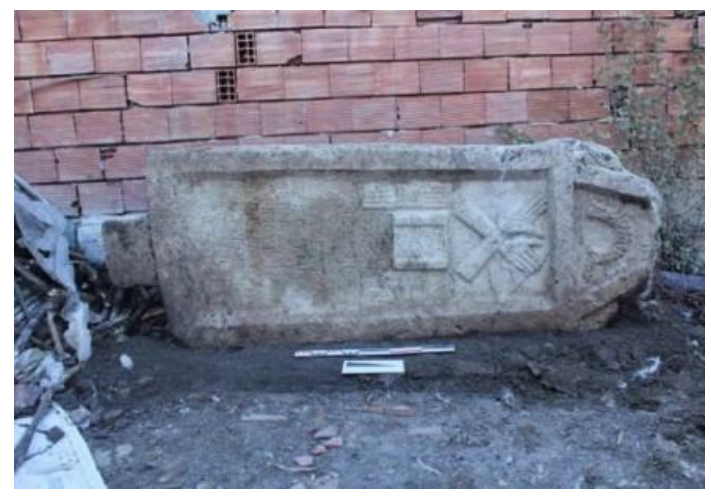

Res. 63: Mezar Steli (Bahçekonak)

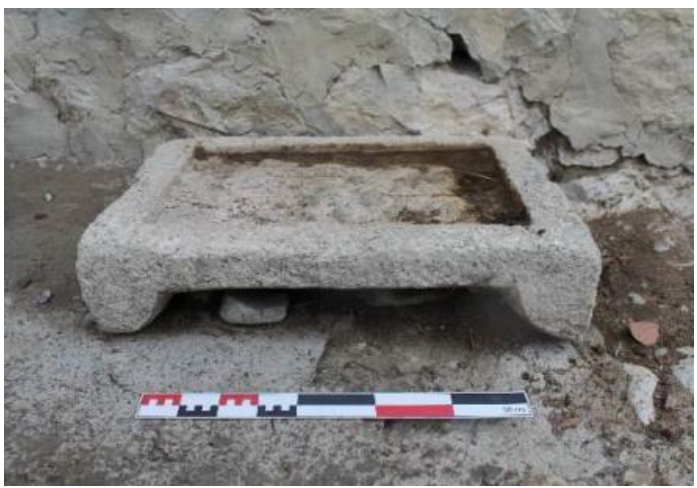

Volume 12

Issue 2

A Tribute to

Assoc. Prof.

Dr. İlknur

Mangir

Karagöz,

April

2020

Res. 64: Ostotek (Yürükçal) 


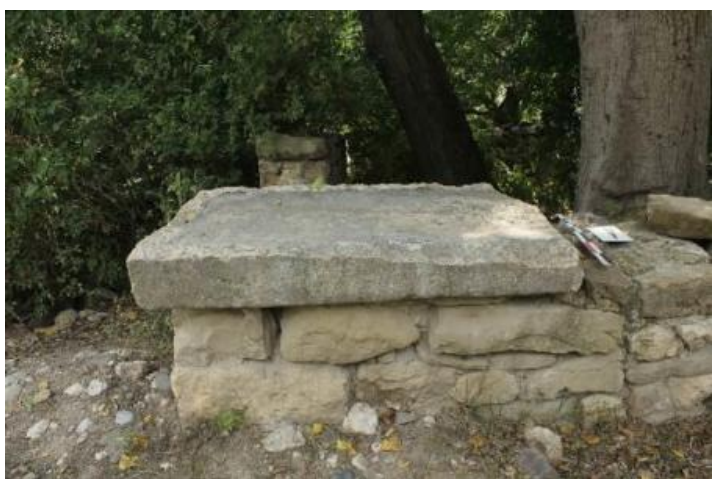

Res. 65: Lahit Tabanı, Hacıkurt Türbesi (Hacıkurt)

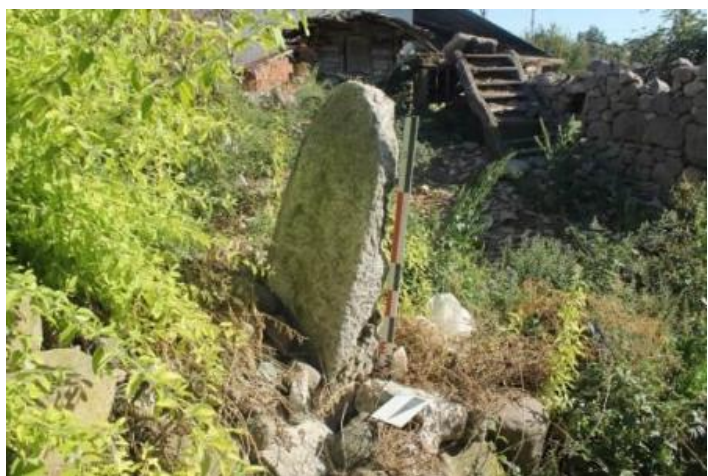

Res. 66: Lahit Kapağı (Bahçekonak)

Issue 2

A Tribute

to Assoc.

Prof. Dr.

İlknur

Mangir

Karagöz,

April

2020

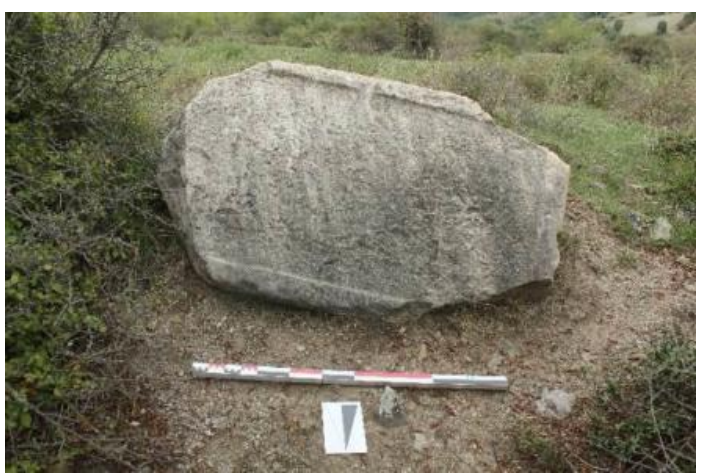

Res. 67: Lahit Kapağı, Ötegeçe Mevkii (Çamlıca)

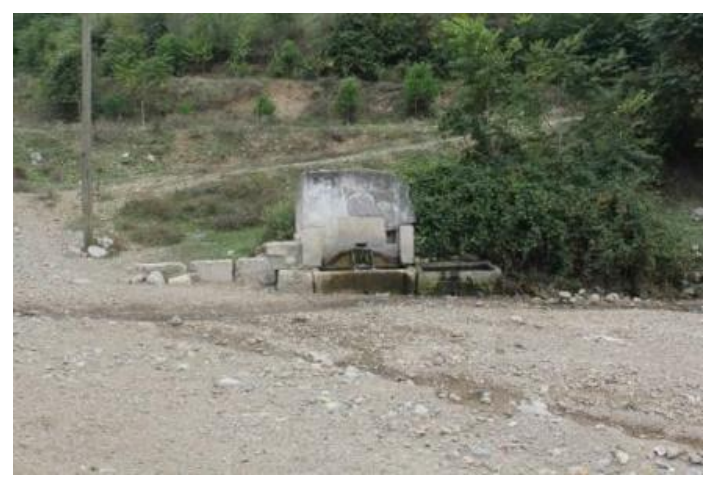

Res. 68: Lahit Tekneleri, Așağıpınarı Mevkii (Doyran)

\section{History Studies}




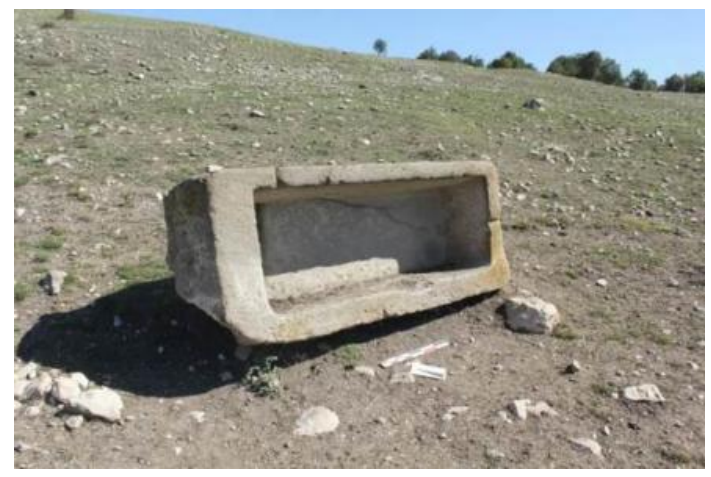

Res. 69: Lahit Teknesi, Maltepe Mevkii (Boğazkoru)

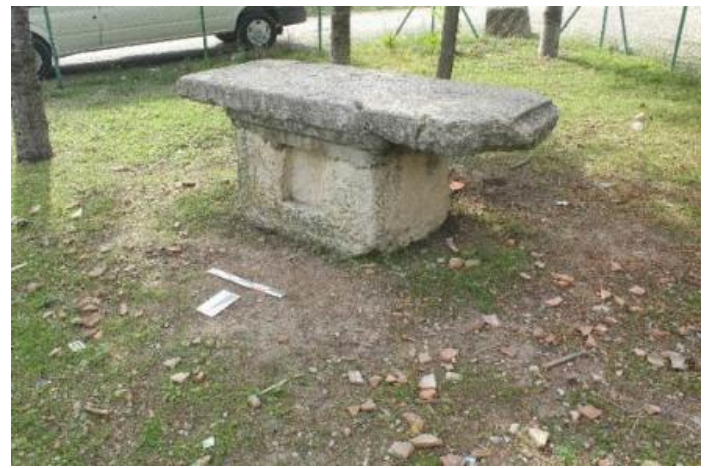

Res. 70: Lahit Kapağı, Mezarlık Mevkii (Karacaören)

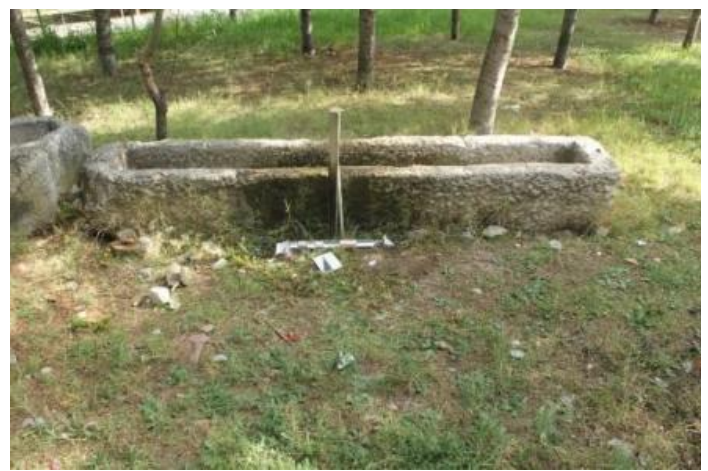

Volume 12

Issue 2

A Tribute to

Assoc. Prof.

Dr. İlknur

Mangir

Karagöz

April

2020

Res. 71: Lahit Teknesi, Mezarlık Mevkii (Karacaören)

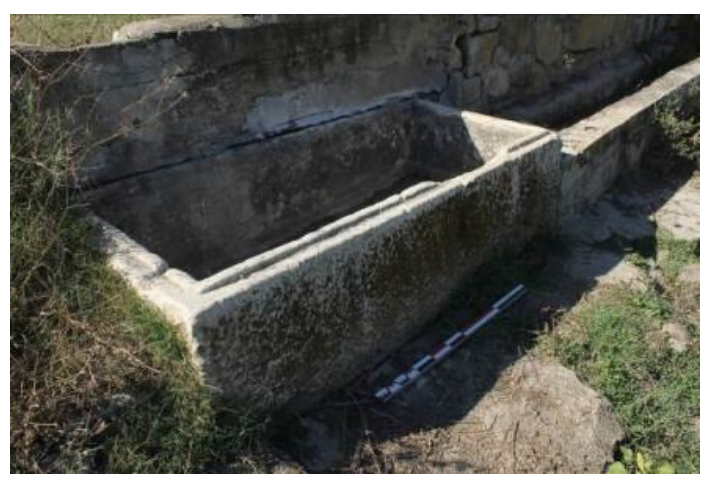

Res. 72: Lahit Teknesi (Bahçekonak)

\section{History Studies}

